\title{
EVALUATION OF \\ CHANNELIZATION AND MITIGATION \\ ON THE FISHERY RESOURCES \\ OF THE ST. REGIS RIVER, MONTANA
}

STATE DOCUMENTS COLLECTION

MAY 311995

MONTANA STATE LIBRARY

$1515 \mathrm{E}$. 6th AVE.

HELENA, MONTANA 59620

OFFICE OF BIOLOGICAL SERVICES FISH AND WILDLIFE SERVICE

U.S. DEPARTMENT OF THE INTERIOR WASHINGTON, D.C. 20240 
The Office of Biological Services was established in FY'75 within the Fish and Wildlife Service to:

Support research, studies, and planning directed toward critical environmental issues

Develop improved ecosystem data for use in resource development actions.

Provide needed authoritative ecological input for Department of Interior programs

Projects of the Biological Services Program are designed to strengthen the Fish and Wildlife Service's ability to predict and accurately assess the impact of land and water developments on fish and wildlife to enhance planned natural resource exploitation.

Current efforts are directed toward five major areas of environmental impact concern related to land and water use and resource development planning, decision making, and operations:

Coastal ecosystems including the Outer Continental Shelf Western energy development and related land and water use Stream alterations and wetlands

Power plant siting, operations, and related delivery systems Development of habitat classification, evaluation, inventory and information systems

This report is an outcome from one of numerous contractual Research and Development efforts conducted on initial FY'75 funding. You comments regarding its usefulness and your suggestions of additional similar information needs are encouraged and may be directed to: 
EVALUATION OF STREAM CHANNELIZATION AND MITIGATION ON THE FISHERY RESOURCES OF THE ST. REGIS RIVER, MONTANA

\author{
by \\ John A. Lund \\ Cooperative Fishery Research Unit \\ Montana State University \\ Bozeman, Montana 59715
}

Contract No. 14-16-0008-737

\author{
Prepared for \\ OFFICE OF BIOLOGICAL SERVICES \\ U.S. Department of Interior \\ Fish and Wildlife Service \\ Washington, D.C. 20240
}


The opinions expressed in this report are those of the authors and not necessarily those of the Office of Biological Services, Fish and Wildlife Service. Any mention of commercial products does not imply endorsement by this agency. 
CONTENTS

\section{Page}

Abstract

ii

List of Tables

iv

Acknowledgements

v

\section{Sections}

I Conclusion

II Recommendations

3

III Introduction 5

IV Methods 8

V Results

VI Discussion

VII References

VIII Appendix 
Stream morphology and gamefish populations of the St. Regis River, Montana were studied during the summers of 1973, 1974 and 1975 to determine the effects of stream channelization caused by highway (Interstate 90 and U.S. 10) and railroad construction. In-stream structures used to mitigate fish losses were also evaluated. Population estimates were made using electrofishing methods on unaltered, altered, altered with mitigating structures and "old" altered study sections. Physical parameters of each section were mapped to show differences between altered and unaltered sections.

Results of the study show that mitigating structures (jetties and random rock clusters) were effective in providing fish habitat comparable to unaltered sections. Fish populations in new channels usually stabilized in approximately one year. Trout populations in "old" altered sections with no mitigation failed to recover to unaltered section levels. Due to aesthetic reasons, fishermen preferred unaltered or partially altered section over altered sections. The number of pools per section as measured by pool-riffle periodicity provided the closest correlation to trout population changes.

This report was submitted in fulfillment of contract no. 14-16-0008-737 by the Montana Cooperative Fishery Research Unit under the sponsorship of the Office of Biological Services, Fish and Wildlife Service. Work was completed as of June 1, 1976. 
No.

1. Types and Amounts (in Percent) of Alterations Present in Altered Study Sections as Measured in 1975.

2. Summary of Physical Parameters Collected on all Study Sections from 1973-1975.

3. Summary of Pool-Riffle Periodicity, Sinuosity, and Gradient Measurements on all Sections from 1973-1975.

4. Percent of Stream Bottom Surface Covered by Each of Seven Size Classes (by Average Diameter) for Study Sections of the St. Regis River Taken in 1974 and 1975.

5. Estimated Fish Cover by Location and Types Measured in 17 Study Sections of the St. Regis River in 1974 and 1975.

6. Range and Average Minimum-Maximum Temperatures from Three Recording Stations on the St. Regis River During the Summers of 1974 and 1975.

7. Measurements of Selected Chemical and Physical Properties Taken at Varying Water Flows During 1974 and 1975.

8. Summary of Discharge Measurements (in $\mathrm{m}^{3} / \mathrm{s}$ ) Taken on the St. REgis River, 1973-1975.

9. Estimated Average Fish Population for all Sections Electrofished in 1973,1974 and 1975.

10. Estimated Fishing Pressure Observed on the St. Regis River for two Periods During the Summers of 1974 and 1975.

11. Estimated Number and Biomass of Gamefish per 1000 Meters of Stream in Each Section of the St. Regis River in 1973, 1974 and 1975.

12. Estimated Population and Average Length by Age Groups Given for years 1973-1975. 


\section{ACKNOWLEDGEMENTS}

The author wishes to extend his gratitude to all who helped in the course of this study. Dr. Richard J. Graham and Mr. Rodney Berg initiated the project and gathered the first year's data. Dr. William R. Gould headed the study for part of 1974. Dr. Richard W. Gregory directed the project and helped prepare the quarterly and final reports.

The U.S. Forest Service, Lolo National Forest, provided aerial photographs of the river and lodging for the crew. Mr. Gordon Haugan, U.S. Forest Service biologist, was especially helpful in supplying background material and in planning the study.

Mr. Barry Schaplow, graduate student, and the student technicians were instrumental in gathering the data.

Dr. Norman G. Benson, National Stream Alteration Team Project Officer, provided guidance and critically reviewed the Manuscript.

The project was financed by the Office of Biological Services, Fish and Wildlife Service, under contract number 14-16-0008-737. 


\section{SECTION I}

\section{CONCLUS IONS}

The results of this study indicate that mitigating structures in altered channels of the St. Regis River have been effective in providing fish habitat comparable to the unaltered sections.

Channel structures produced stream bottom contours similar to those found in unaltered sections.

Where mitigating structures failed during high water (section2), trout populations (biomass and fish greater than $18 \mathrm{~cm}$ ) were significantly lower than in the unaltered control.

Gamefish populations in altered sections with mitigation recovered from construction work in about one year.

Erosion and turbidity caused during channel construction and the initial unstable channel bottom were of relatively short duration and seemed to have no long-term effects on the biology of downstream areas. New channels usually stabilized after one high-water period.

Changes in water temperature and water chemistry due to channel alterations were not detected.

Trout populations in "old" altered sections (more than 50 years old) with no mitigation failed to recover to unaltered section levels.

Properly constructed jetties and random rock clusters of large riprap material produced good, economical trout habitat. 
Fishermen favored unlatered or partially altered stream sections, compared to altered sections, probably for aesthetic reasons.

The following problems associated with channelization were not alleviated: (1) loss of stream bank vegetation, (2) destruction of the natural stream aesthetics, and (3) loss of stream length in most cases. 


\section{SECTION II}

RECOMMENDATIONS

Implementation of the following recommendations should help mitigate habitat losses due to channelizations along high gradient trout streams like the St. Regis River.

1. Alter original stream channels only when absolutely necessary, and then keep alterations to a minimum. When a lengthy channelization occurs, meander the new channel as much as possible to correct ditchlike appearance and to retain original stream length.

2. Vegetation (especially trees and shrubs) along new channels should be retained, if possible, to provide bank stability and shade. When topsoil and vegetation are lost, banks should be sloped and topsoil replaced and reseeded down to the high-water mark. Trees and shrubs such as red dogwood, willow, common chokecherry, alder and birch should be planted along stabilized stream banks.

3. When riprap is needed to hold the stream in a new channel, it should be covered with subsoil and topsoil down to high-water mark and then revegetated with grass, trees and shrubs.

4. Jetties, random rock clusters and other in-stream devices used to create pools must be properly engineered to withstand the annual high-water and th occasional floods wich occur. If riprap material is used to construct mitigating devices, it must be large enough to prevent hydraulic water pressure from spreading it out and burying it.

5. In grave1-bottomed streams, jetties and other mitigating devices should be placed 5-7 stream widths apart (alternating from each streambank) to 
match pool-riffle and meander sequences found in unaltered sections.

6. Mitigating structures must be placed in the currents close to thalweg to be most effective in providing trout habitat.

7. Random rock clusters and jetties could be used together (cluster near outer end of jetty) to create larger mid-channel pools. 


\section{SECTION III}

\section{INTRODUCT ION}

GENERAL

Stream alteration and channelization projects have generally benn considered as detrimental to fish and wildlife populations in the disturbed areas. The reduction of both warm water and cold water fish populations by stream alteration has been documented by several authors, including Alvord and Peters ${ }^{1}$, Elser ${ }^{2}$, Irizarry ${ }^{3}$, Congdon ${ }^{4}$ and Tarplee, Louder and Weber ${ }^{5}$. Populations of gamefish were depleted as much as $95 \%$ in these studies. Efforts to improve trout habitat in stream has met with varying degrees of success. Hunt ${ }^{6}$ and Shetter, Clark and Hazzard ${ }^{7}$ have shown good success in improving brook trout populations in two unaltered streams. Latta ${ }^{8}$ had only marginal success in improving brook and brown trout populations in a Michigan stream. Trout populations in a channelized section of the Weber River, Utah were restored to unaltered levels by various channel structures (Barton, White, Winger and Peters ${ }^{9}$ ).

\section{OBJECTIVES}

The major objectives of this study were to determine the effects of channel alterations and rehabilitation measures in channelized areas on the cold water sport fisheries of the St. Regis River. The study included: (1) a comparison of physical, biological and chemical characteristics of "old" and "newly" altered areas with those of unaltered areas; (2) a determination of the overall effectiveness of mitigating devices in restoring fish habitat; (3) making recommendations for mitigating biological losses from future stream alterations.

\section{DESCRIPTION OF AREA}

The St. Regis River is located in the mountains of northwestern Montana just east of the Idaho-Montana border. It flows southeasterly for about $63 \mathrm{~km}$ 
(39 miles) to its confluence with the Clark Fork River near St. Regis, Montana (Figure 1). The elevation of the river ranges from $1707 \mathrm{~m}$ (5600 ft) to $805 \mathrm{~m}$ (2640 ft) msl. Average discharge recorded at the USGS gaging station near St. Regis (drainage area $=785 \mathrm{Km}$ ) was $15.9 \mathrm{~m} / \mathrm{s}$ (562 cfs) for a 15-year period ending in 1973. The maximum recorded discharge of $312 \mathrm{~m} / \mathrm{s}$ (11,000 cfs) occurred during a flood on May 19, 1954, and a minimum discharge of $1.2 \mathrm{~m}^{3} / \mathrm{s}$ (4I cfs) on December 30, 1968. Average stream width is about 13 meters, but varies greatly from the headwaters to the mouth.

The river flows through a narrow valley and is paralleled by U.S. Highway 10 and a railroad for most of its length. In 1962, approximately 68 percent of the stream length received some degree of channel alteration (Alvord and Peters ${ }^{1}$ ). Most of the alterations were due to highway and railroad construction projects which straightened and riprapped the river in many areas. Approximately $8 \mathrm{~km}$ of channel were relocated resulting in the loss of $1.5 \mathrm{~km}$ of stream length. The construction of Interstate 90 has resulted in additional channelization and relocation sites because of the canyon's narrow areas and constrictions of the river caused by the railroad and Highway 10 grades.

The following species of gamefish were found to be present in the river during the study: rainbow trout (Salmo gairdneri), cutthroat trout (Salmo clarki), brown trout ( $\underline{\text { Salmo }} \underline{\text { trutta }}$ ), brook trout (Salvelinus fontinalis, dolly varden trout (Salvelinus malma) and mountain whitefish (Prosopium williamsoni). Cutthroat trout and brook trout were the major species in the upper half of the river. Mountain whitefish, rainbow trout and brown trout were the major species in the lower half. Nongame species present included longnose sucker (Catostomus catostomus), largescale sucker (Catostomus macrocheilus) and slimy sculpin (Cottus cognatus). Only a few of the two sucker species were found in the lower half of the river, while sculpin was common the full length of the river. 


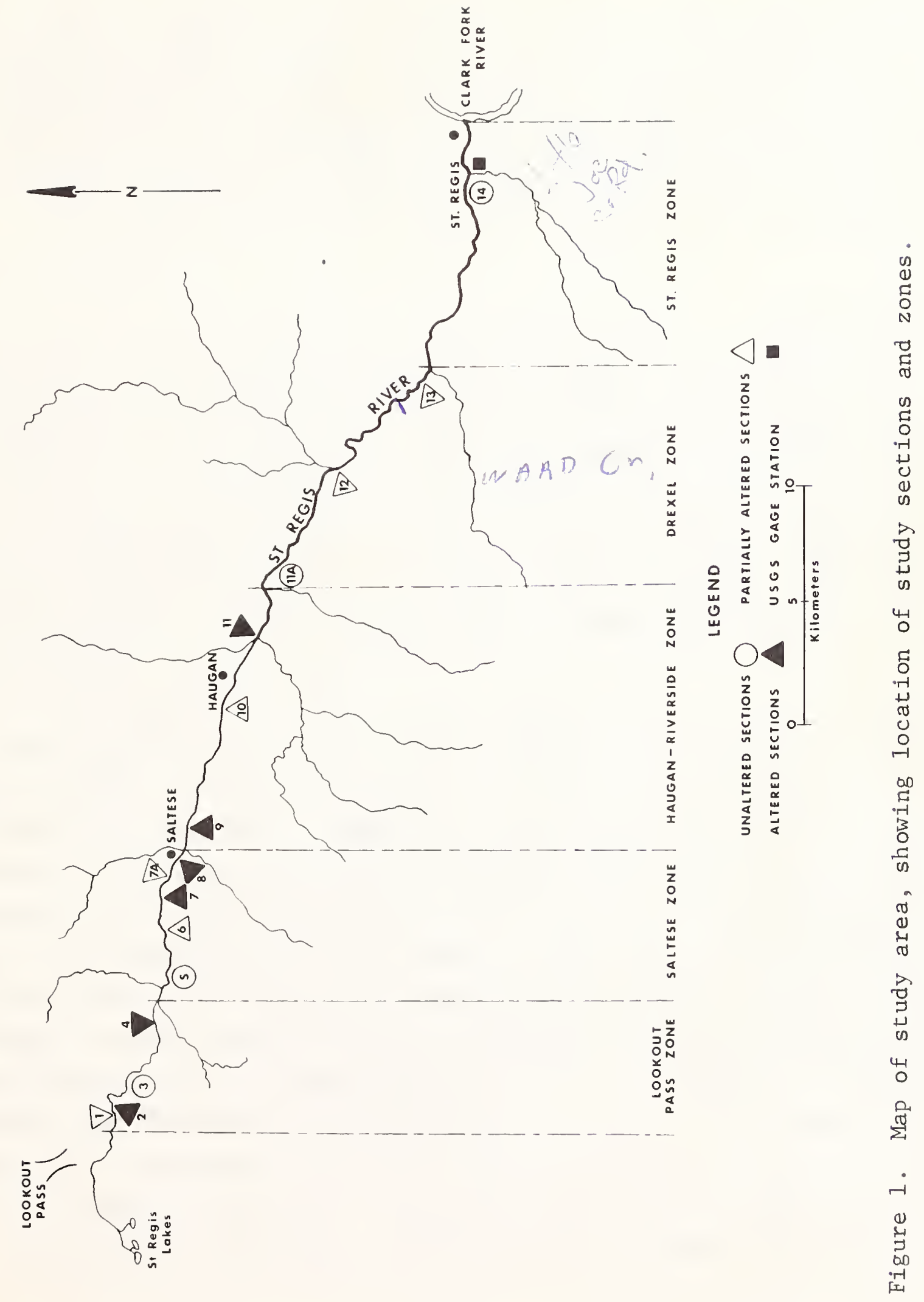




\section{SECTION IV}

METHODS

\section{GENERAL}

The river between Borax Springs and the mouth was divided into five zones based primarily on discharge changes resulting from the entrance of the larger tributaries. Sixteen study sections were selected from highway construction plans and by onsite inspection so the various altered and unaltered channel types could be included. Comparison of fish populations were generally made between sections within each zone.

\section{CHANNEL MAPPING}

Al1 study sections were mapped at least once during the three years of the study (1973-1975). Study sections averaged $831 \mathrm{~m}$ in length, ranging from 361-1518 m. Measurements were taken during the usual low flow period (late August - early September) each year. Transects were taken at regular intervals (3-15 $\mathrm{m}$ apart) across each section, but never at an interval wider than the average width (water edge to water edge) of the section. Measurements taken at each transect included channel width, water depth, fish cover, bottom materials, and thalweg velocity. Depths were recorded at $0.6 \mathrm{~m}$ ( $2 \mathrm{ft}$ ) intervals when the channel was less than $12 \mathrm{~m}$ (40 ft) wide and at $1.2 \mathrm{~m}$ ( $4 \mathrm{ft}$ ) intervals when the channel width was greater than $12 \mathrm{~m}$. Islands and large rocks were excluded in computing average depth. Thalweg velocities were measured at the deepest point along the transect using a Teledyne Gurley meter adjusted (0.6 from the surface) to measure the average volocity. The type of bottom materials present was estimated by observations through a plastic viewer $(30.5 \mathrm{~cm}$ in diameter) at regular intervals (approx. 60 readings/section). Pools were defined as areas having depths equal to or greater than one standard deviation of the average thalweg depth for the section. Pools were usualiy denoted by lower thalweg velocities (usually less than $0.5 \mathrm{~m} / \mathrm{s}$ ). Gradients vere calculated for each section using a surveyor's transient and rod. Discharge measurements were taken at 7 stations using standard USGS techniques. Temperature readings were also taken during the summers at three stations using Taylor thermographs. 
Fish cover was measured in 1974 and 1975 along transects placed at 15-24 m intervals. All cover $1.5 \mathrm{~cm}$ ( $5 \mathrm{ft}$ ) on either side of the transect line was measured. The total area of fish cover provided by overhanging brush, debris, roch shelves, and undercut banks was recorded. The cover was classified as being submerged, 0-60 cm, 60-150 cm, or greater than $150 \mathrm{~cm}$ above the water. The total fish cover mapped in each section varied from 20 percent in the shortest section to 12 percent in the longest section.

\section{POPULATION ESTIMATES}

The fish population of each section was sampled using a $1500 \mathrm{w}, 110$ volt A.C. generator and 0-400 volt D.C. rectifier unit. The electrofishing gear was usually operated from a small flat-bottomed boat. Captured fish were anesthetized with MS-222 (Tricane methanesulfonate), weighed, measured, finclipped, and redistributed throughout the section. Blocking nets were placed at the lower end of each section (mostly in 1975) prior to each electrofishing operation. The mark and recapture method for making population estimates was used. Usually one or two mark and/or recapture trips were required per section. A period of at least 24 hours was allowed to elapse between mark and recapture runs.

The Bailey modification of the Petersen estimator (formula 3.7 in Ricker ${ }^{10}$ ) was used to estimate the population of each major species in each section. Number and biomass estimates were made by length and age groups using a computer program developed by the Montana Fish and Game Department. The computer program also provided $80 \%$ confidence limits on al1 condition factors of fish over $13 \mathrm{~cm}$ ( 5 inches) and on all population estimates. The gamefish populations of each section were tested against other sections in the zone to determine if population numbers and/or weights were significantly different. Trout populations were not considered significantly different if the $80 \%$ confidence intervals were overlapping. 


\section{FISHERMAN SURVEYS}

Fishing pressure counts were made during the summers of 1974 and 1975. Counts were made by driving along the river between section one and $\mathrm{St}$. Regis and counting the number of people fishing. Census days and hours were randomly selected without replacement. At least one weekend day each week and all holidays were included. A creel survey was also conducted in 1975 to determine hourly catch rates, species composition, and fishing methods. Interviews were conducted after each pressure count trip and at the end of the day to get as many completed fishing trips as possible. 


\section{SECTION V}

RESULTS

\section{STREAM MORPHOLOGY}

Five types of stream habitats were studied. These were classified as partially altered (PA), "old" altered (OA), "new" altered (NA), altered with mitigation (AM), and unaltered (UA). All stream habitat types were represented by at least two study sections.

\section{$\underline{\text { Lookout Zone }}$}

Four study sections were selected in zone I to represent habitat types found in this mountainous headwater area. Section 1 (PA) had 33 percent of its length altered during construction of I-90 (Table 1). Section 2 (AM) was relocated and channelized by I-90 construction, step dams were added for mitigation. Section 3 (UA) was the control section for zone 1. Section 4 (OA) was straightened by railroad construction over 50 years ago.

\section{Saltese Zone}

Five study sections were selected in this "upper" canyon area of the river. Section 5 (UA) was used as a control section for zone II. This section was moved upstream $1.5 \mathrm{~km}$ to a more representative unaltered site in 1975. Section 6 (PA), (60 percent altered), was partly altered by old and recent highway construction, but retained some unaltered areas. Section 7 (AM) is a narrow, highly channelized section relocated by I-90 construction, random rocks were added for mitigation. Section 7A (NA) was added in 1975 because it was similar and adjacent to sections 7 and 8 . Section 8 (AM) was relocated and straightened by I-90 construction (less gradient and wider than section 7), jetties were added to this section. 


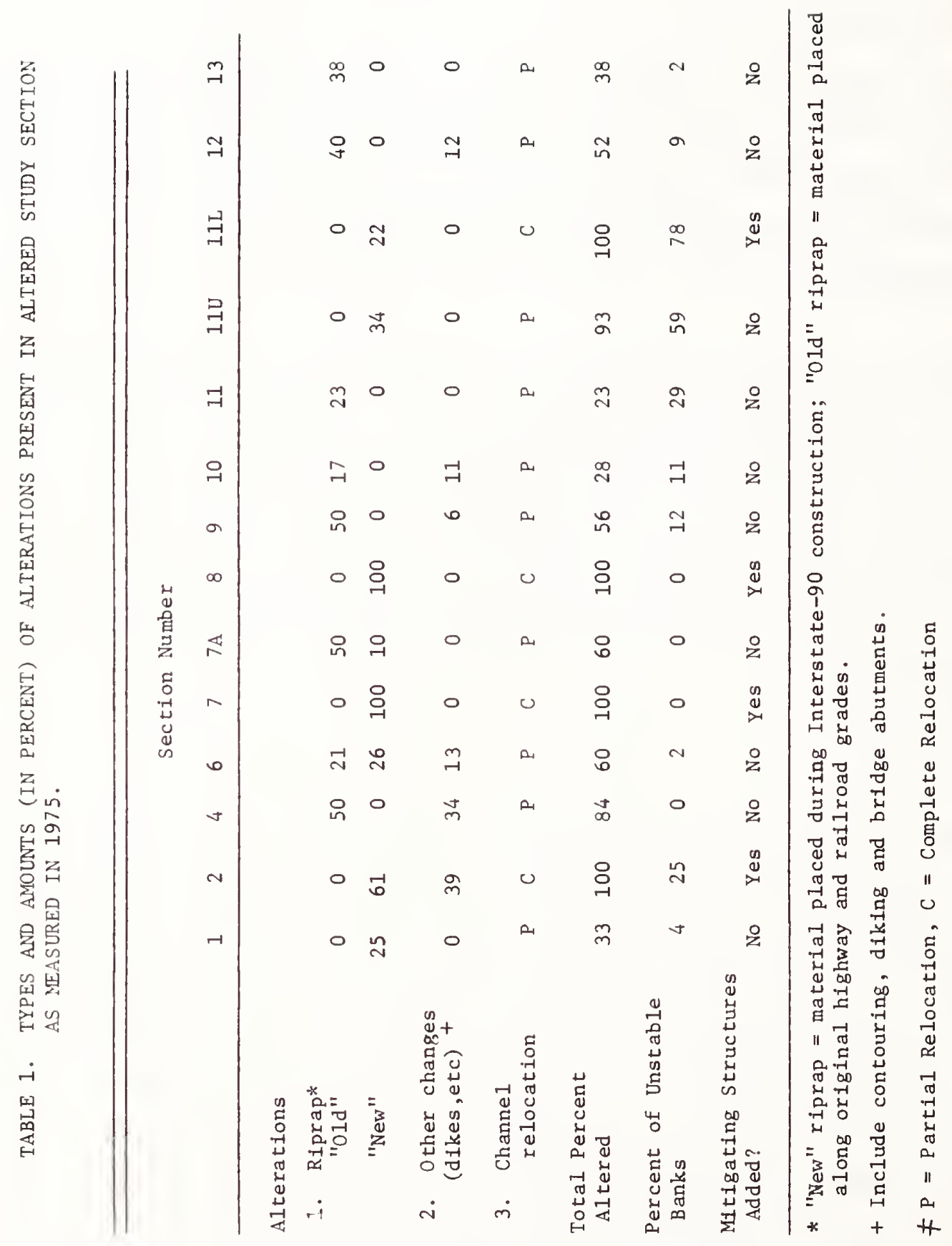


Haugan-Riverside Zone

Five study sections were selected in this wide and flat portion of the drainage. Section 9 (OA) was altered by railroad construction over 50 years ago. Section 10 (PA) has two altered areas (28 percent of tota1) caused by railroad construction. Section 11 (PA) had one area of relocation and channelization (23 percent) before it was relocated to a new channel. Section $11 U$ (NA) is the upper half of relocated section 11 which was moved in January 1975. Section 11L (AM) comprises most of the lower half of relocated section 11 and has jetties for mitigating structures. Section IIA (UA) was the downstream control section for zone III.

Drexel Zone

Two study sections in the "lower" canyon area were added to provide data prior to I-90 construction. Section 12 (PA) was altered in several areas (52 percent) by Highway 10 and railroad encroachment. Section 13 (PA) was also altered (38 percent) by Highway 10 and railroad grades.

St. Regis Zone

One study section was selected in this lower, flat portion of drainage. Section 14 (UA) is a low gradient section used as a control for sections 12 and 13. This section also provided baseline data before I-90 construction. 


\section{Physical Parameters}

Physical parameters obtained by mapping channels of study sections on the St. Regis River are shown in Table 2. The general trends shows average width, depth, thalweg depth and thalweg velocity increasing in a downstream direction. There were, however, some exceptions to this trend. Section 7 (AM) had a 30 percent loss of width compared to the section directly upstream. This was caused by the straightening and compressing of the section between the old highway and Interstate 90. Decreases in average depth and thalweg depth were noted for sections 7A (NA), 8 (AM), 9 (OA), $11 \mathrm{U}$ (NA), and 12 (PA).

A coefficient of variation (page 62, Snedecor and Cochran ${ }^{11}$ ) was calculated for each parameter (Table 2) to measure the Variability of each section. By averaging the percent variations (average width, depth and thalweg depth), an overall variation for each section was obtained. Unaltered study sections (3, 5, 11A and 14) have a 51 percent variation average compared to 48 percent for partially altered sections $(1,6,10,11,12$ and 13), 48 percent for sections altered with mitigating structures (2, 7,8 and 11L), 44 percent for "newly" altered sections (7A and 11U), and 30 percent for "old" altered sections (4 and 9). Percent variations from the mean depth and thalweg depths are directly related to the quantity and/or size of pools present in each section. The unaltered sections, since they have the highest average variations, appear to have one of the pre-requisites for good trout habitat, that being the highest number and/or sizes of pools. Altered sections with mitigating devices also had relatively high percent variations, as did the partially altered sections. "Old" altered sections without mitigation showed a low percent variation, indicating little or no recovery from channelization. 


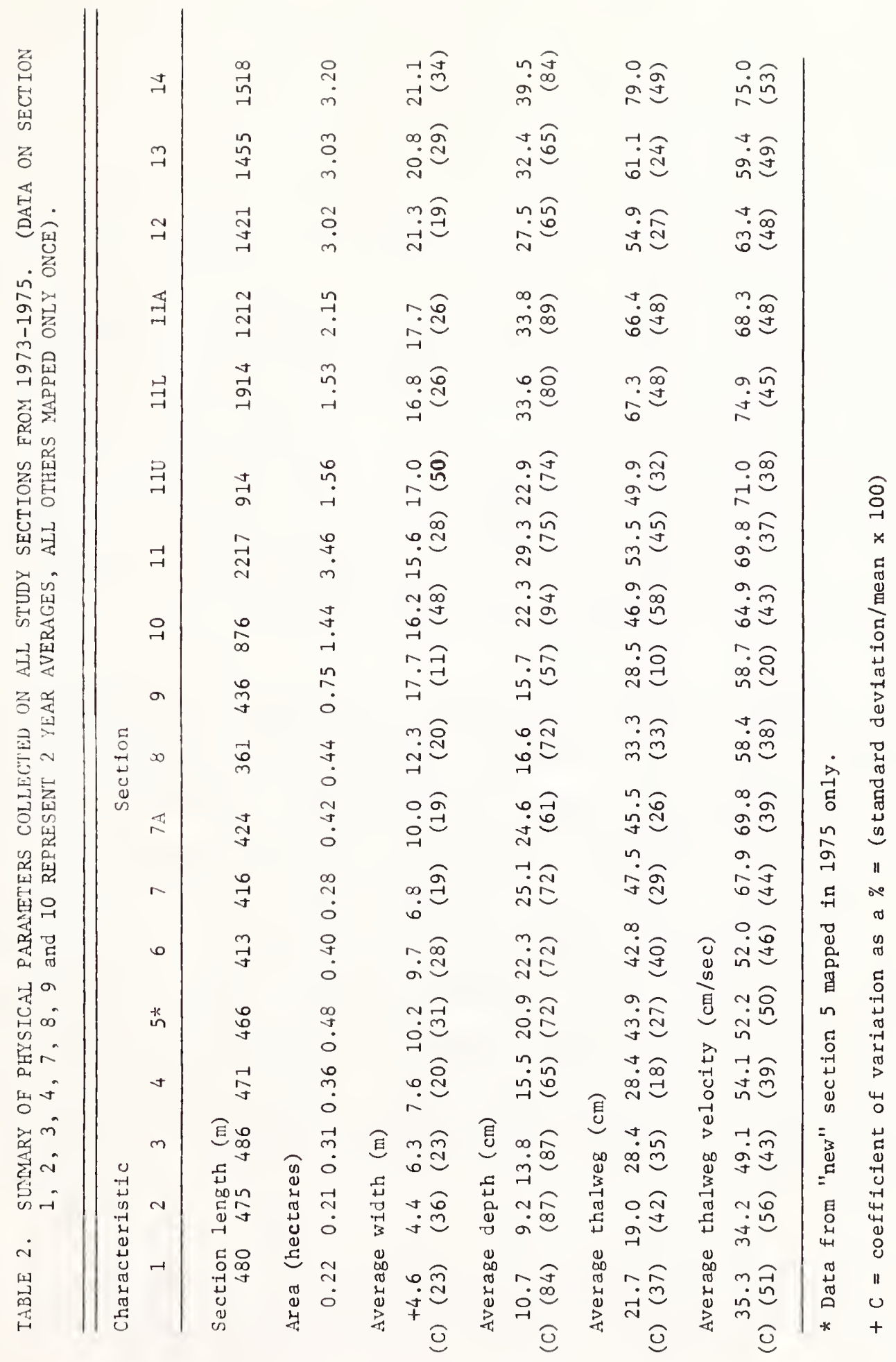


A natural stream channel, whether nonmeandering (straight) of meandering usually has an undulating bed. According to Leopold, Wolman and Miller, "alternates along its length between deeps (pools) and shallows (riffles) at a repeating distance of 5 to 7 widths". This is true of all streams having bottom material larger than coarse sand. (Leopold, Wolman and Miller ${ }^{12}$ ). Pool-riffle periodicity is the average distance between pools or riffles measured in average stream widths for the section. Ratios for this study (Table 3) were 6.0 for altered sections with mitigation, compared to 6.3 for un-altered sections, 8.0 for partially altered sections, 12.0 for altered sections without mitigation and 12.4 for "old" altered sections. The average ratio of 6.3 (range 4.6 to 7.7 ) for unaltered sections and 6.0 (4.1 to 9.3) for altered sections with mitigation compares favorably with 5 to 7 width figure stated above. The altered sections with no mitigating devices had little pool development as noted by the high pool-riffle ratios.

The thalweg, in natural stream conditions, also tends to move back and forth across the channel every 5 to 7 channel widths, even in straight reaches. The ratio of thalweg length to down valley distance (defined as sinuosity) is a measure of the relative degree of thalweg and channel meandering. The ratio of unaltered sections averaged 1.22, compared to 1.17 for partially altered sections, 1.15 for altered with mitigating structures, 1.11 for altered without mitigation and 1.05 for "old" altered sections (Table 3). Channelization and bank stabilization with riprap eliminates meanders and reduces thalweg movement in most cases. In altered sections, thalweg movement failed to return unless mitigating structures were used to deflect the current back and forth.

Channel gradients (Table 3) generally decreased in a downstream direction. The sharp increase in gradient at section 7 was partially due to loss of stream length during channelization of this area. Other variations from the trend appear to be due mainly to natural changes in the drainage. 


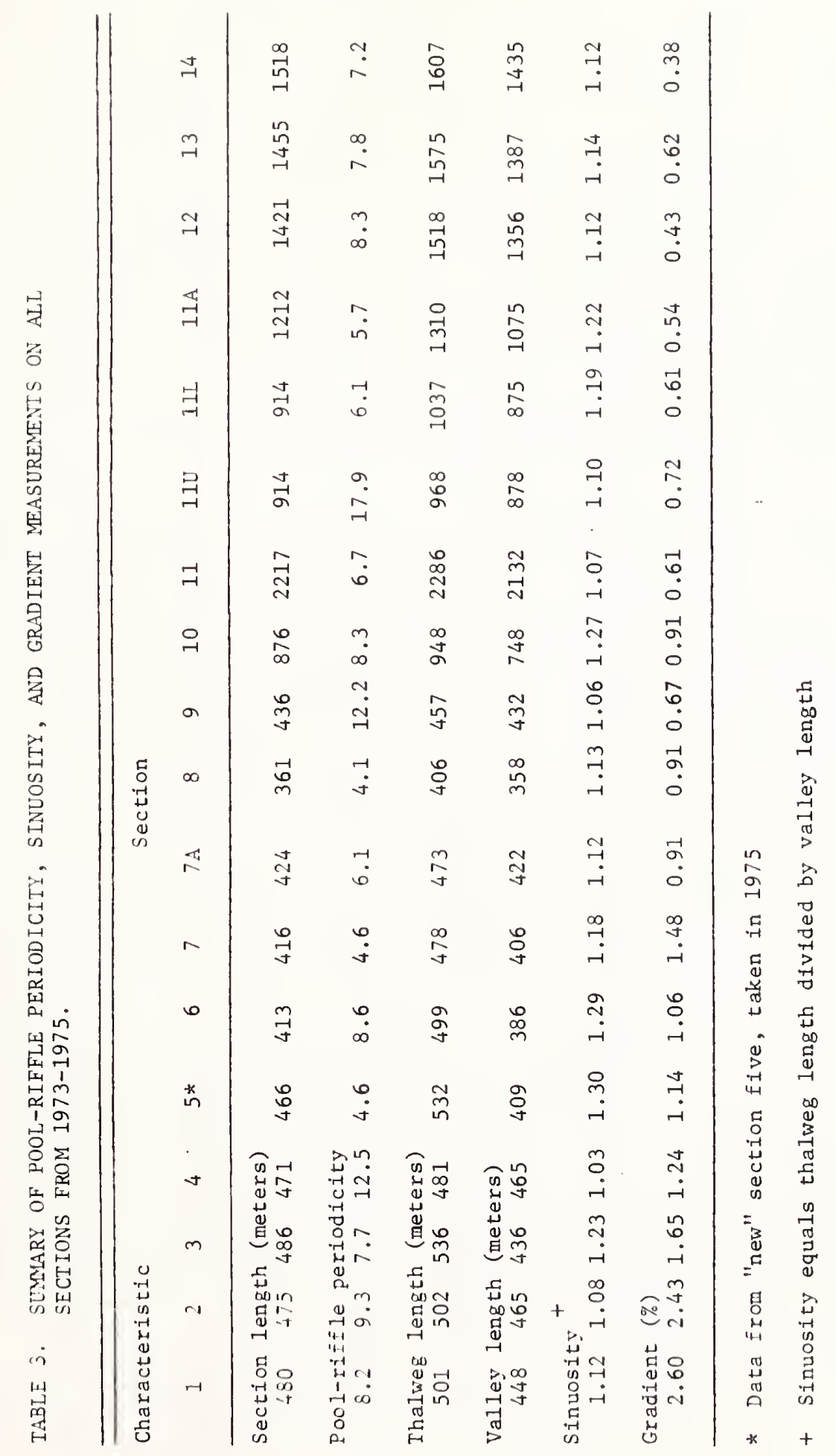




\section{Bed Materia1}

Size classes of bed material at each study section are shown in Table 4. The average size of bed material in each section generally decreased in a downstream direction. Material greater than $7.5 \mathrm{~cm}$ ( 3 in. average diameter) ranged from 76 percent of total in section 1 and 3 to 48 percent in section 14. Section 7 had the highest amount (34 percent) of material over $30 \mathrm{~cm}$ (12 in). This was due to the placement of random rock clusters on the streambed to improve fish habitat. Sections $11 \mathrm{~A}$ and 14 each had the highest average ( 8 percent) of fine material less than $0.3 \mathrm{~cm}$ ( 0.1 in). Although fine material increased in the lower sections, these areas were localized and did not prevent natural reproduction of fish.

\section{Fish cover}

The amount, type and location of fish cover in each section is presented in Table 5. Submerged fish cover is considered the most important type because it provides both protection and a place to rest away from the main current. Since measurements were taken during the yearly low water period, submerged cover measured at that time is available to fish year around. Submerged fish cover ranged from a high average of $151 \mathrm{~m}^{2} / 1000 \mathrm{~m}$ for unaltered sections to a low of $40 \mathrm{~m}^{2} / 1000 \mathrm{~m}$ in the "old" altered sections (Table 5). Cover 0-60 cm above the water would be of greater importance during high water periods when it would be submerged. This type of cover (mostly overhanging brush, debris and rock ledges) ranged from a high average of $225 \mathrm{~m}^{2} / 1000 \mathrm{~m}$ for unaltered sections to a low of $30 \mathrm{~m}^{2} / 1000 \mathrm{~m}$ for altered sections with mitigating structures. Cover higher than $60 \mathrm{~cm}$ above the water (groups 3 and 4) provides only 1imited cover, if any, for trout. The latter two types may be of more value in providing shade. Most of the newly altered sections had no cover over 60 cm due to construction practices. 


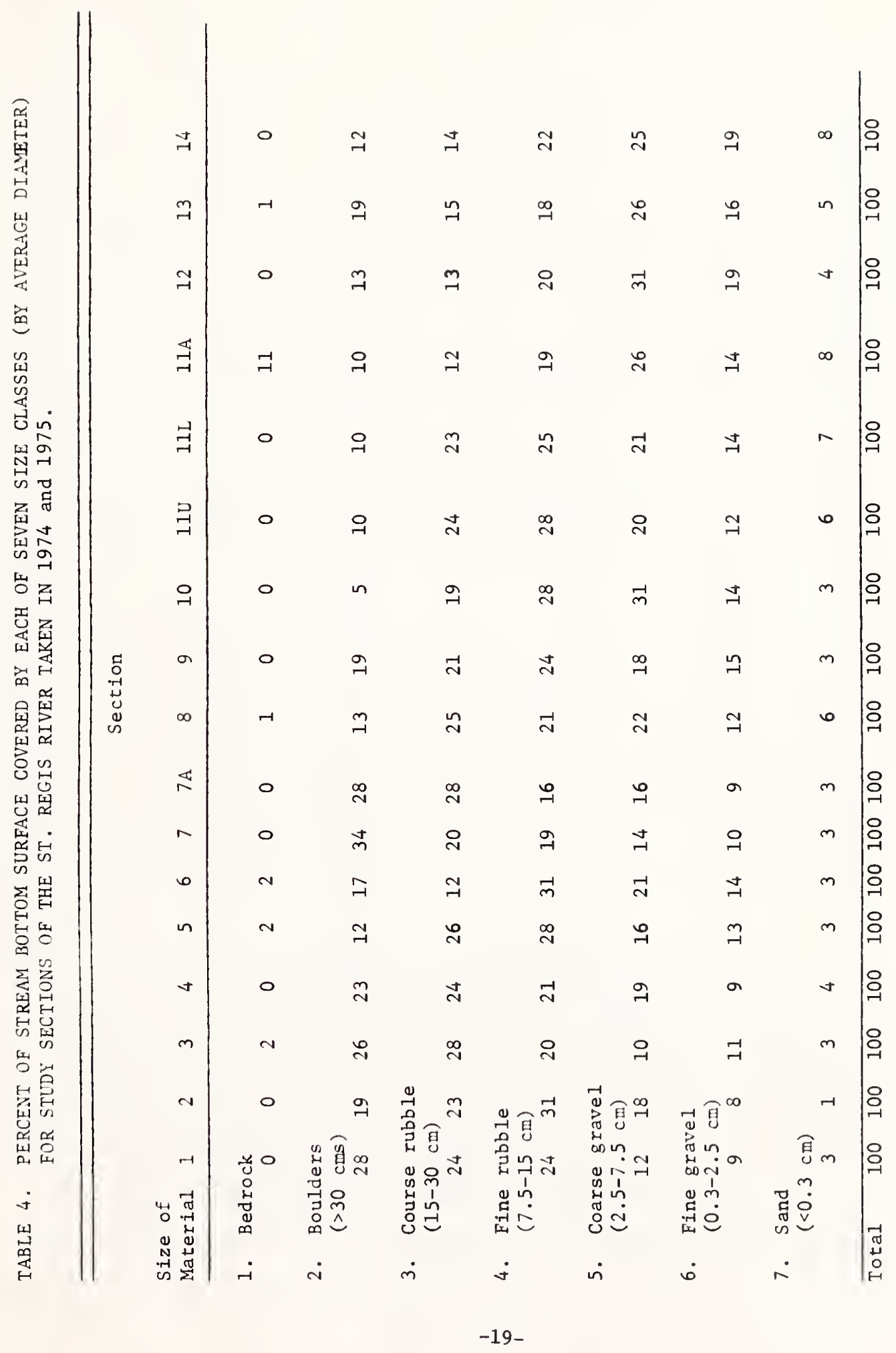




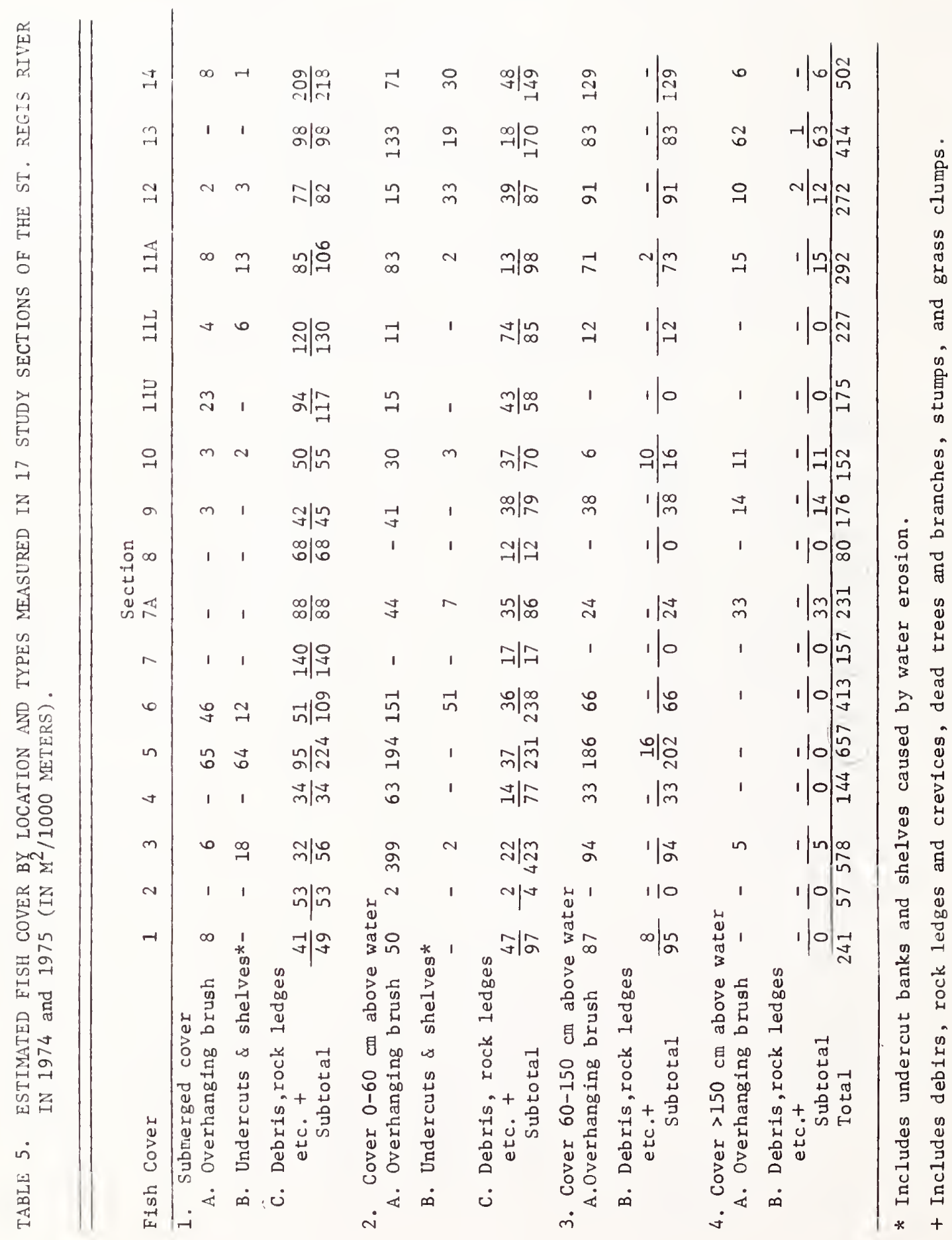




\section{STREAM CHARACTERISTICS}

\section{Stream Temperatures}

Maximum-minimum temperature variations were recorded at three locations in 1974 and 1975 (Table 6). Temperature trends were similar at all stations during the periods the three thermographs were in operation. Average maximum and minimum temperature increased in a downstream direction both years. The average temperature (averaging maximum and minimum temperatures) at each station shows a $2.5^{\circ} \mathrm{C}$ increase between section 3 and 11 in 1974 , and a $1.7^{\circ} \mathrm{C}$ increase in 1975. The average change between sections 11 and 14 was $0.8^{\circ} \mathrm{C}$ in both 1974 and 1975. Diurnal differences between average maximum and minimum temperatures (Table 6) at the Lookout, HaugenRiverside and St. Regis stations were $4.3^{\circ}, 4.2^{\circ}$ and $4.5^{\circ} \mathrm{C}$ in 1974 and 4. $4^{\circ}, 4.2^{\circ}$ and $4.5^{\circ} \mathrm{C}$ in 1975 , respectively. The highest temperature recorded during the project was $19.3^{\circ} \mathrm{C}\left(66.7^{\circ} \mathrm{F}\right)$ at the St. Regis station on July 30,1975 . The lowest recorded temperature was $3.1^{\circ} \mathrm{C}\left(37.5^{\circ} \mathrm{F}\right)$ at the Lookout station on June 12, 1974.

Higher than normal daytime stream temperatures were suspected in the channe1ized areas: however, attempts to measure these changes were frustrated by the entrance of ground water. Summer stream temperatures appear to be favorable for all species of trout and whitefish present with maximum temperatures well below critical levels.

\section{Water Chemistry}

The St. Regis River has been described as having a relatively low productivity compared to other mountain streams. Water samples taken at the start of zone 1 (station A) and at the end of each succeeding zone (Table 7) bear this out. Total alkalinity and hardness exceeds $50 \mathrm{ppm}$ only during low water periods at station F. Nutrients (orthophosphate, nitrate and nitrite nitrogen) were also measured and found to be at low levels. Turbidity readings also remained low, except when channel alterations were being made above station $D$. 
TABLE 6. RANGE AND AVERAGE MINIMUM-MAXIMUM TEMPERATURFS FROM THREE RECORDING STATIONS ON THE ST. REGIS RIVER DURING THE SUMMERS OF 1974 AND 1975.

\section{Stations}

\begin{tabular}{ccc}
$\begin{array}{c}\text { Lookout } \\
(\mathrm{Sec} .3)\end{array}$ & $\begin{array}{c}\text { Haugan-Riverside } \\
(\mathrm{Sec} .11)\end{array}$ & $\begin{array}{c}\text { St. Regis } \\
(\mathrm{Sec} .14)\end{array}$ \\
\hline
\end{tabular}

Elevation (meters)

1170

951

817

Distance between stations $(\mathrm{km})$
21.5
25.9

June 11 - Sept. 17, 1974

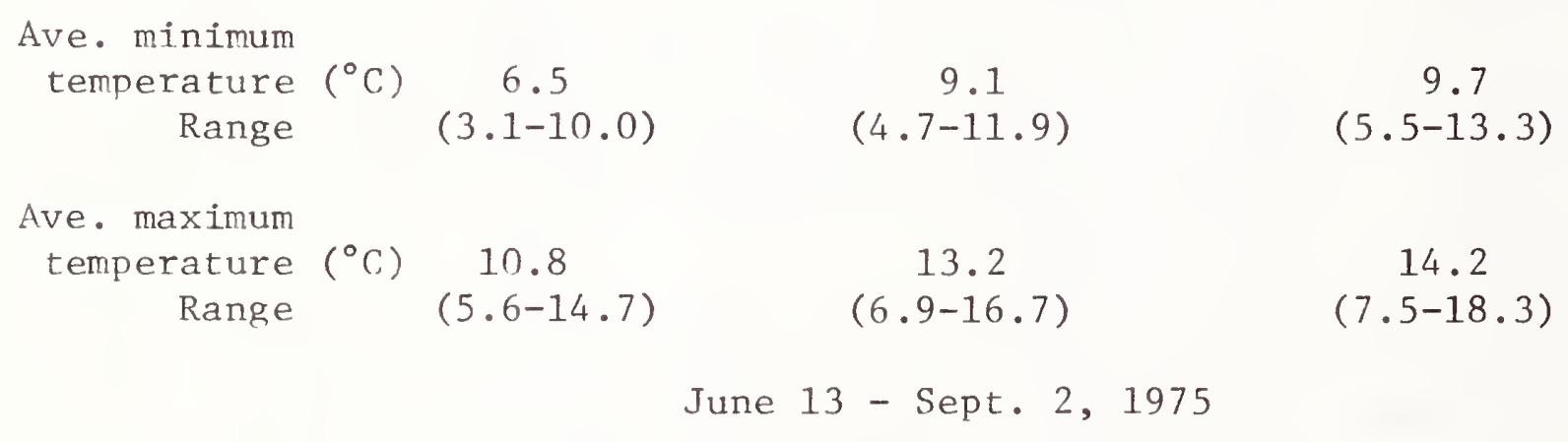

Ave. minimum temperature Range

$\left({ }^{\circ} \mathrm{C}\right) \quad 7.3$

$(3.3-10.8)$

9.1

$(4.7-12.2)$

9.9

(5.3-13.6)

Ave, maximum temperature

$\left({ }^{\circ} \mathrm{C}\right) \quad 11.7$

13.3

14.1

Range

(4.7-16.4)

(6.7-17.5)

(6.9-19.3) 


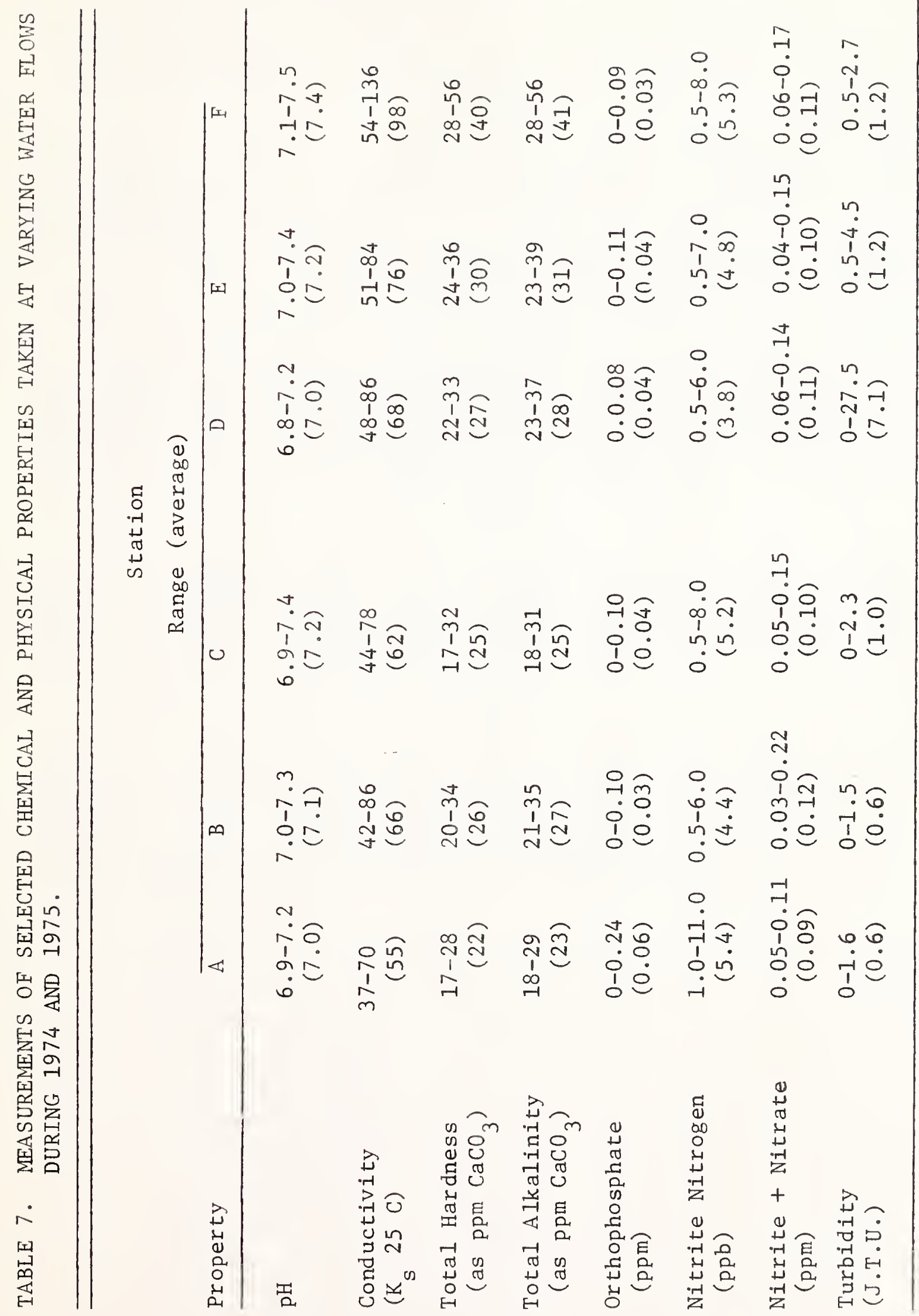




\section{Discharge Measurements}

Discharge measurements were taken at seven stations on the St. Regis River in 1973, 1974 and 1975 (Table 8). The river shows a steady increase in flow from station 1 (Borax Springs, start of Section 1) to the USGS gage station (Figure 1). The river has a wide range of discharges during a normal year. Flows at station 1 are from 40 to 60 times greater during the runoff period than during the low water period. At the USGS station, discharge readings were 15 to 25 times greater during runoff than during the low flow period. A maximum discharge of $273 \mathrm{~m}^{3} / \mathrm{s}(9,640 \mathrm{cfs})$ was recorded at the USGS gage station on January 16, 1974 (during a flood). The lowest USGS flow reading was $1.7 \mathrm{~m}^{3} / \mathrm{s}$ (60 cfs) recorded on September 12, 1973 . The flood of January 1974 had a detrimental effect on the fish populations in the river. Besides displacing fish downstream, most of the redds of fall spawners (brook and brown trout, mountain whitefish) were destroyed. 
TABLE 8. SUMNARY OF DISCHARGE MFASUREMENTS (IN $\mathrm{M}^{3} / \mathrm{S}$ ) TAKEN ON THF ST. RECIS RIVER, 1973-1975.

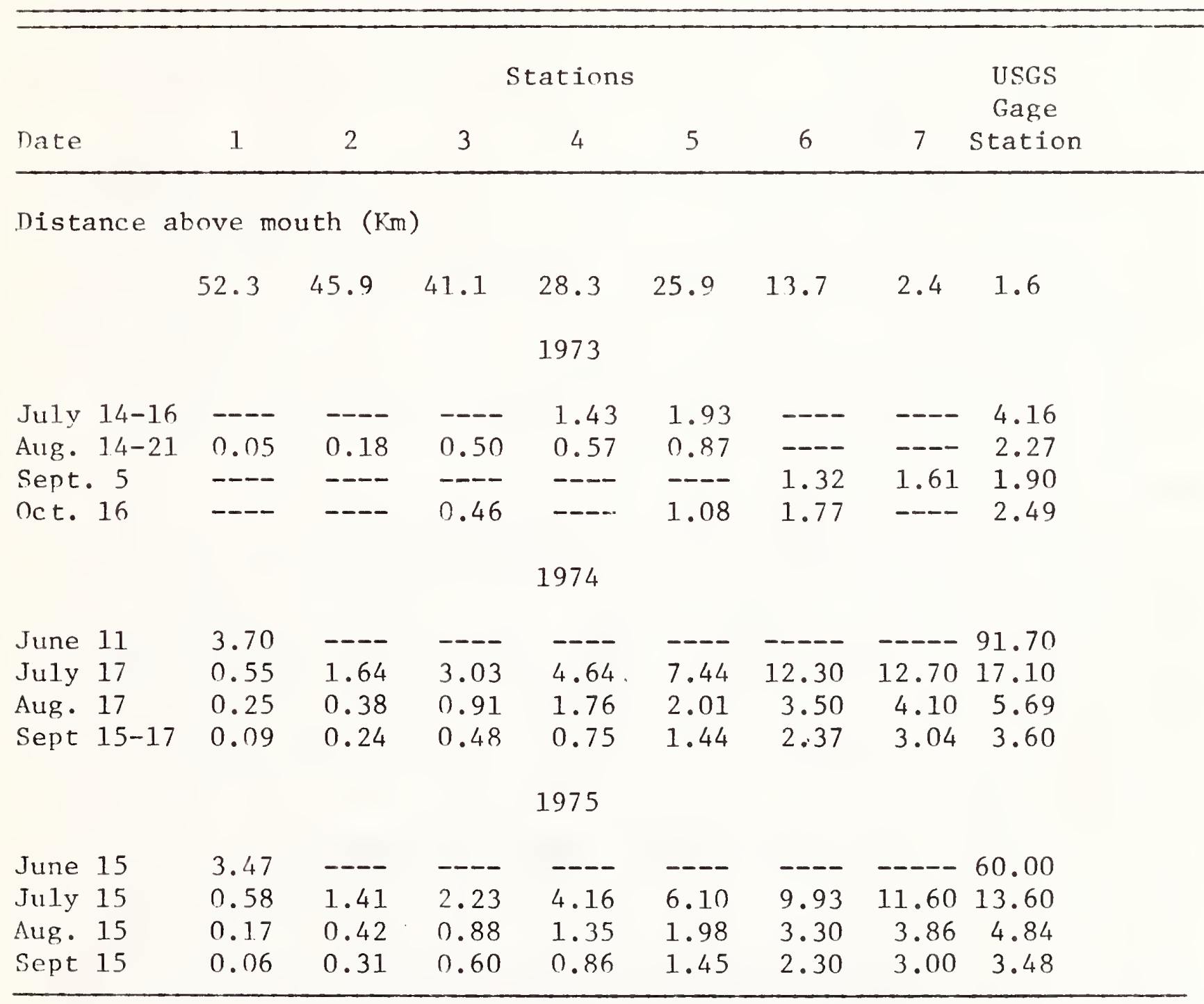




\section{GAMEFISH POPULATION ESTIMATES}

Population estimates by length groups (Table 11, Appendix) and by age groups (Table 12, Appendix) were made on most sections from 1973 to 1975. Petersen mark and recapture runs were made each summer from midJuly to early September. Each section, however, was electrofished during approximately the same period each year.

The estimated number of each trout species in each section was averaged over the 3-year period (Table 9). Estimated whitefish populations for each section in 1975 are also shown. The first length group for each species was adjusted to include all age $\mathrm{I}^{+} \mathrm{fish}$. The largest fish taken for each species in each section formed the upper limit of the last length group.

Lookout Zone

An average of point estimates for trout populations in zone I shows no significant difference between section 1 (PA), section 2 (AM), or section 3 (UA). In populations of these three sections however, were significantly higher ( 80 percent confidence level) that the population of section $4(\mathrm{OA})$, exceeding it by as much as 100 percent (Table 9). The higher number of trout in section 2 was due to the large number of age $\mathrm{I}^{+}$cutthroat found there in 1974 (Table 12, Appendix).

The number of trout greater than $18 \mathrm{~cm}$ (7 in) was significantly higher in sections 1 and 3 than in sections 2 and 4. The number of larger trout in section 3 was 2, 38 and 55 percent greater than in sections 1, 2, and 4, respectively.

A singificantly higher average biomass of trout (Figure 2) was also found in section 3 compared to the other sections in zone I. The average weight of trout in section 3 exceeded those of sections 1,2 , and 4 by 18 , 32, and 63 percent, respectively. Estimated gamefish standing crops for each section in 1975 are shown in Figure 3. The small numbers and weight of whitefish found in zone I did not affect section comparisons. 


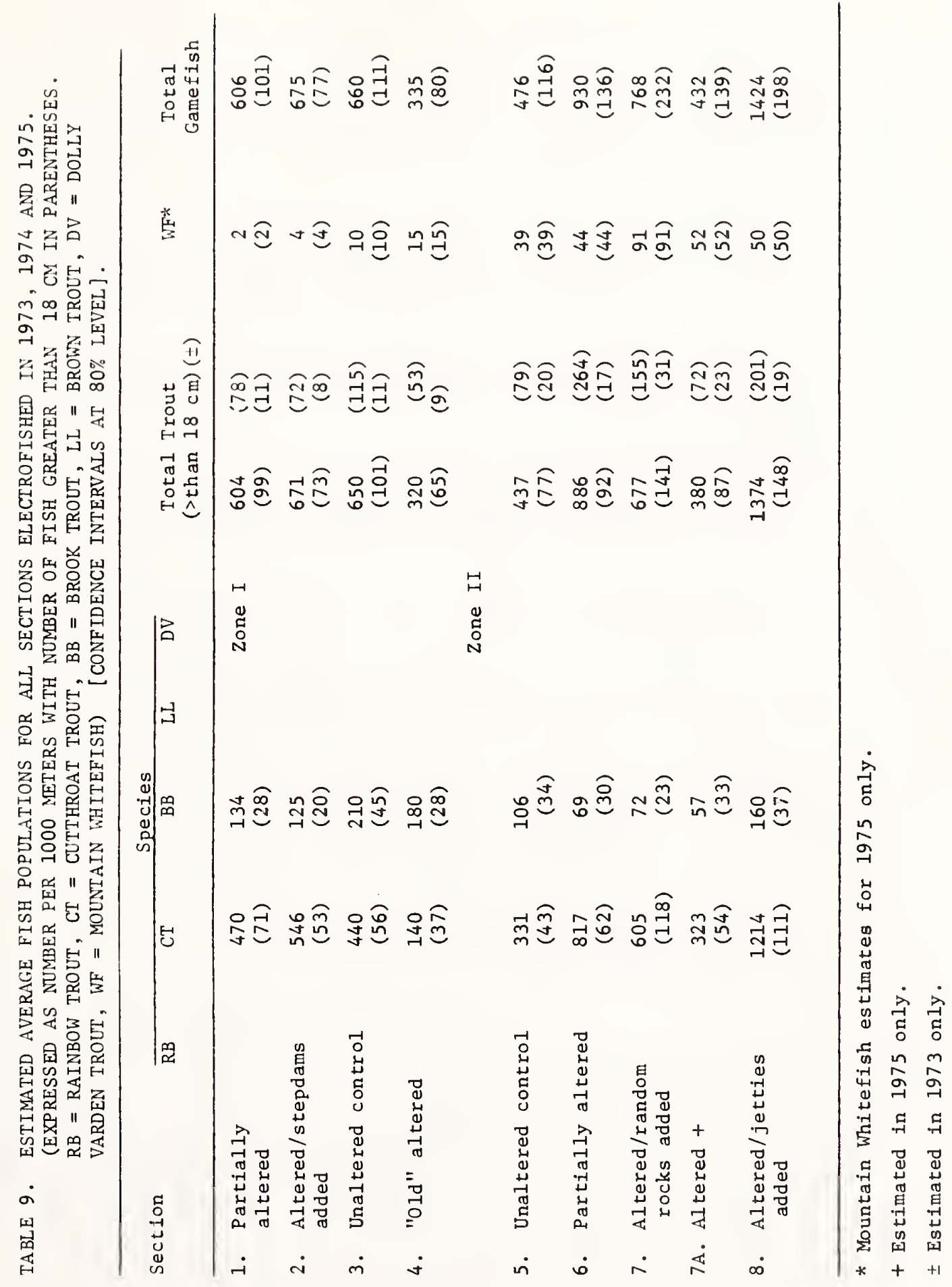




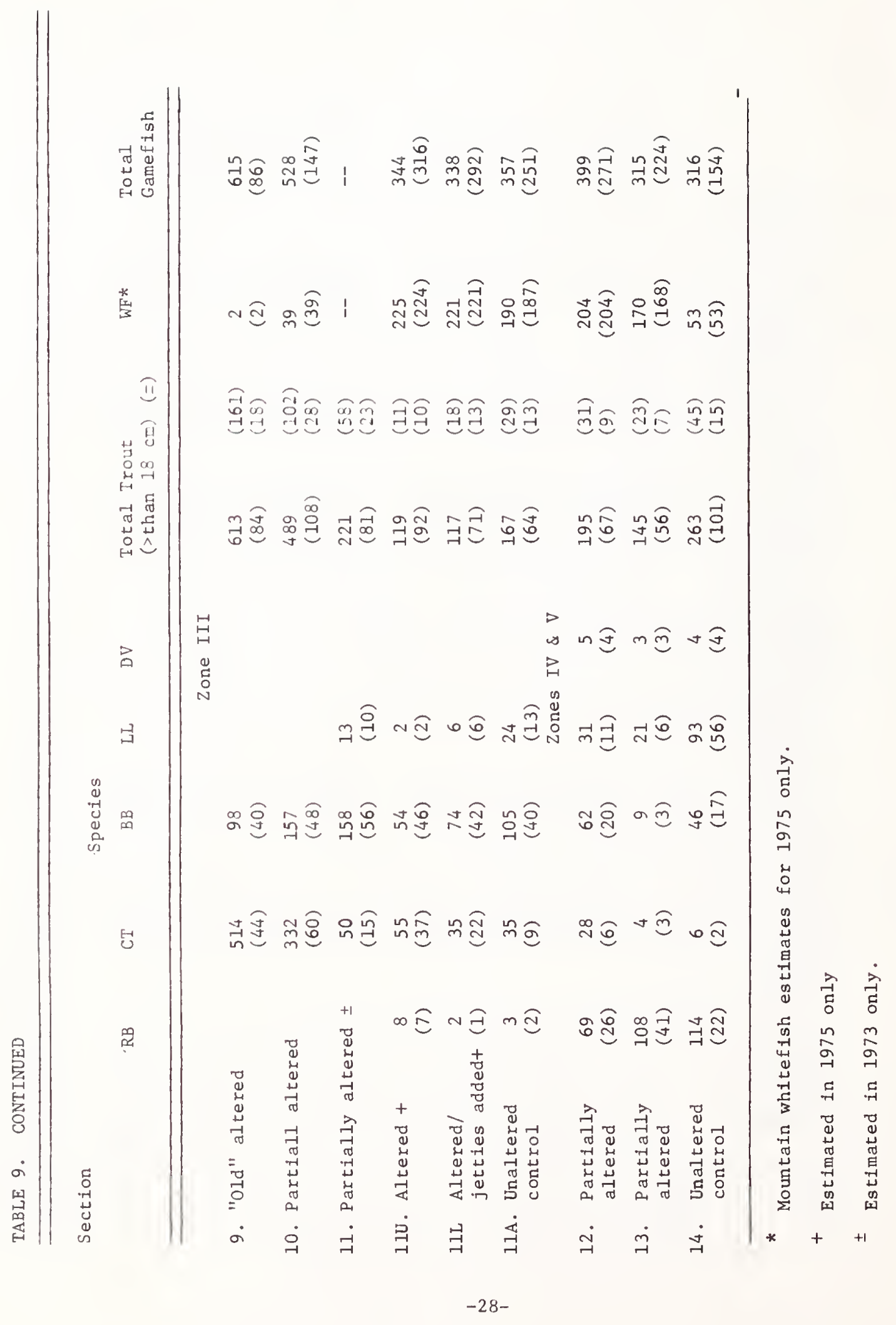




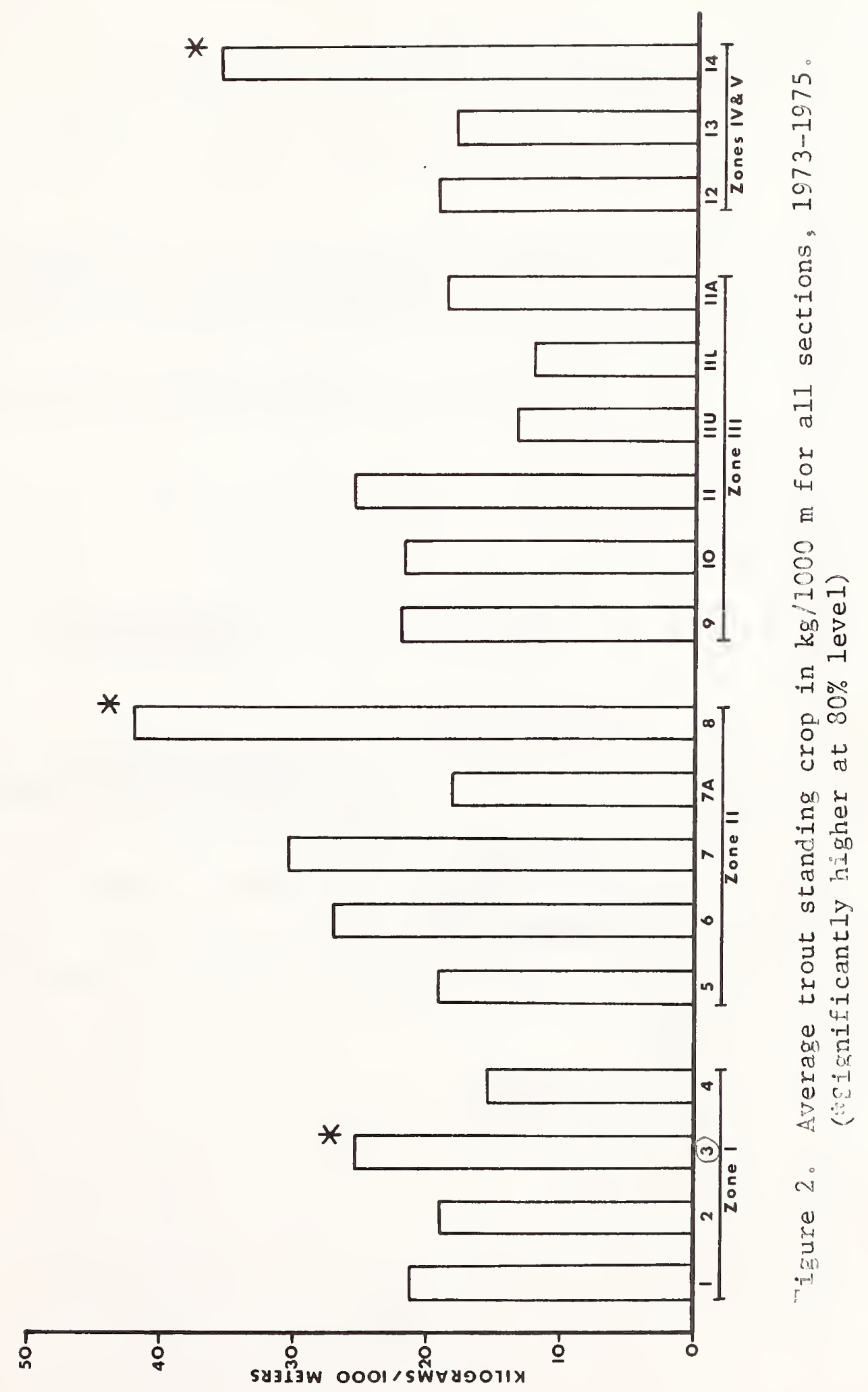




\section{Saltese Zone}

The highest average number of trout in zone II was found in sections 8 (AM). Numbers in this section exceeded those in section 5 (UA), section 6 (PA), section 7 ( $\mathrm{AM}$ and section 9 (OA) by 214, 55, 102 and 124 percent, respectively, and were significantly higher in each case.

The number of trout greater than $18 \mathrm{~cm}$ in zone II was significantly higher in sections 7 and 8 , compared to sections 56 , and 9 . Numbers in section 8 exceeded those in sections $5,6,7$, and 9 by $92,61,5$, and 76 percent, respectively.

The average trout standing crop was also higher in section 8 (Figure 2), exceeding section 7 (the closest section) by 43 percent. The addition of whitefish biomass (Figure 3) to the trout estimates in 1975 raised section 7 above section 8 . Sections 7 and 8 were both significantly higher than sections $5,6,7 \mathrm{~A}$ and 9 .

Section 7A was added in 1975 as an "altered control" section for sections 7 and 8 . The sections with mitigating structures ( 7 and 8 ) exceeded section 7A by 120 and 167 percent in total trout and by 173 and 251 percent, respectively, in trout greater than $18 \mathrm{~cm}$ (Table 11, Appendix). Section 9 was compared to zone II sections even though it has a higher stream flow. Section 9 is very close to zone II (Figure 1) and has a similar species composition. 


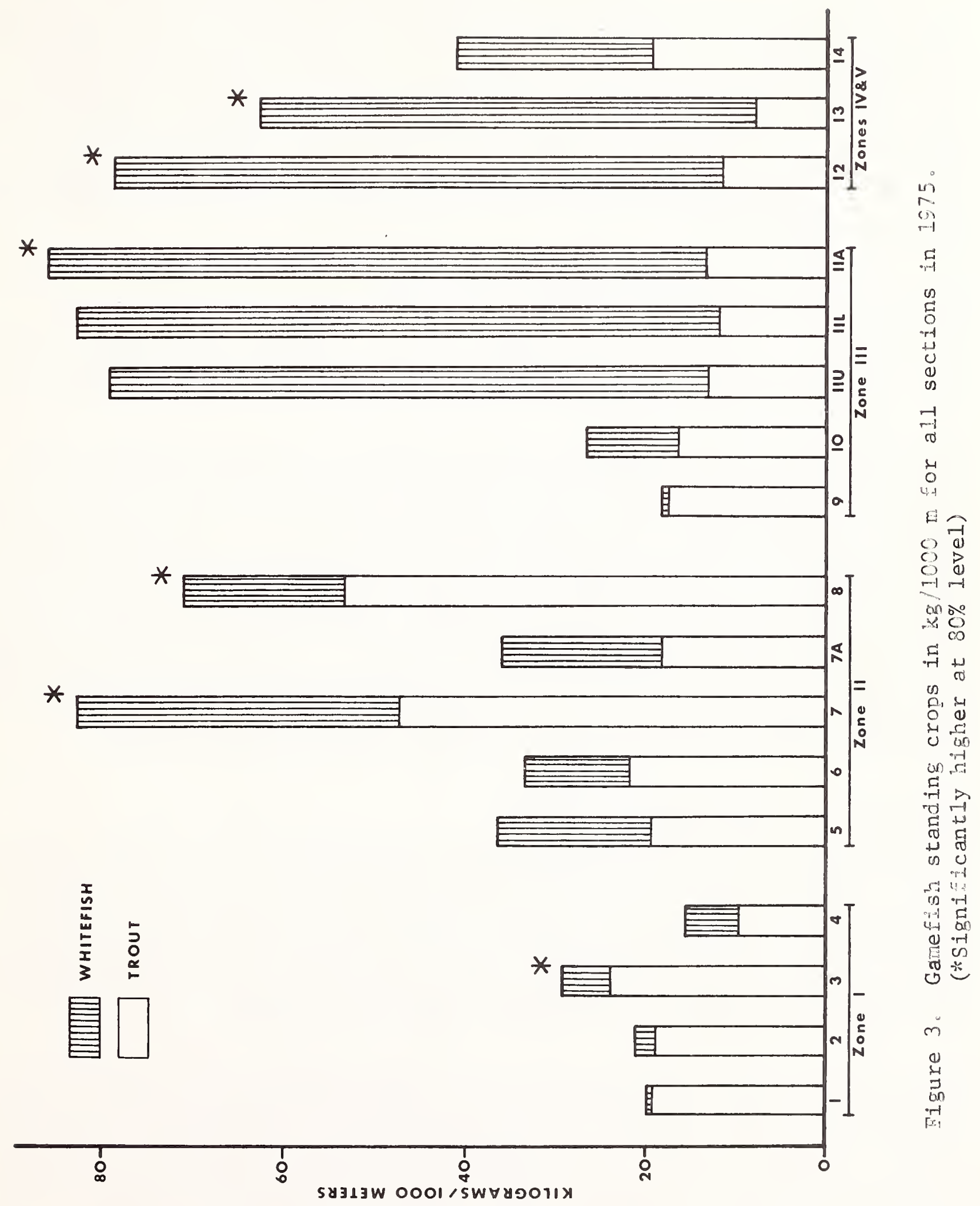


Haugan - Riverside Zone

In zone III, mountain whitefish became the dominant species in the river. Section 10 marked the upper limit of whitefish reproduction and separated the upper, predominantly trout, sections from the lower, predominantly whitefish, sections. Section 10 (partially altered) had the highest average number of trout, compared to section 11 (partially altered) and 11A (unaltered control). Whitefish numbers in section $11 \mathrm{~A}$ were significantly higher than those of section 10 .

There was no significant difference in trout biomass averages (Figure 2) for zone III. Total gamefish biomass in 1975, however, was significantly higher in sections 11A, $11 \mathrm{~L}$ and 11U, as compared to section 10 (Figure 3).

The recovery of fish populations in sections $11 \mathrm{~L}$ (AM) and $11 \mathrm{U}$ (NA) were evaluated in 1975 after the stream had been relocated there from section 11. The two new sections had recovered 53 and 54 percent of these trout numbers in a 7-month period. The numbers of trout greater than $18 \mathrm{~cm}$ was not significantly different among the three sections. Whitefish in sections $11 \mathrm{~L}$ and $11 \mathrm{U}$ had also reached levels equivalent to that of section $11 \mathrm{~A}$ in both numbers and biomass (Table 9 and Figure 3). Section $11 \mathrm{~A}$ had a 4 and 9 percent higher gamefish biomass than sections $11 \mathrm{~L}$ and $11 \mathrm{U}$, respectively, in 1975.

\section{Drexel and St. Regis Zones}

Baseline population estimates were made in the Drexel and St. Regis zones prior to the start of I-90 construction in this area. Post-construction estimates were also planned; however, construction did not occur in time. Population data from the two zones can be compared since species compositions and stream flows (Table 8 , stations 6 and 7) are similar.

Section 14 (UA) had the highest average trout populations, exceeding those of sections 12 and 13 (PA) by 35 and 81 percent, respectively. The number of trout greater than $18 \mathrm{~cm}$ was significantly higher in section 14 compared to sections 12 and 13 (Table 9). The standing crop biomass (Figure 2) was also significantly higher, exceeding sections 12 and 13 by 88 and 103 percent, respectively. 
Sections 12 and 13, however, had a significantly higher whitefish biomass and total gamefish biomass in 1975 (Figure 3), even though section 14 contained more trout. The biomasses of gamefish in sections 12 and 13 were 90 and 52 percent higher, respectively, than the biomasses in section 14 .

Fish populations in zones IV and $V$ are characterized by relatively large numbers of whitefish and few cutthroat trout. Rainbow and brown trout effectively replace cutthroat numbers in these lower zones (Table 9). 


\section{FISHERMEN SURVEY}

Fishing pressure counts were made during the summers of 1974 and 1975 on the St. Regis River (Table 10). The fishing season runs from the third Saturday in May through November on this river. Pressure counts were made during the period when fishing was heaviest (July and August). High water in late May and June discourages fishing at this time. Little fishing occurs during the fal1 hunting seasons.

\section{Pressure Counts}

Estimated total fishing pressure went from 3682 hrs in 1974 to 5207 hrs in 1975, an increase of 41 percent. This is equal to a pressure of $65.7 \mathrm{hrs} / \mathrm{km}$ and $92.8 \mathrm{hrs} / \mathrm{km}$ in 1974 and 1975, respectively. Approximately 52 percent of the fishing occurred on weekends and holidays, even though these days equaled only 31 percent of total days. Zones IV and V (47 percent of censused length) received 68 and 51 percent of the total fishing pressure in 1974 and 1975 , respectively. A stocking program, which ended with the 1973 plant, may have stimulated the increased fishing pressure in these zones. The highest fishing pressure $(200 \mathrm{hrs} / \mathrm{km})$ during the two years was recorded on sections 12 and 13 in zone IV (Table 10). Unaltered sections (Table 10) showed 57 percent greater fishing pressure than the altered sections for the first three zones (mean of 1974 and 1975).

\section{Cree1 Survey}

A 1 imited creel survey of fishermen in 1975 showed a catch rate of $0.85 \mathrm{fish} / \mathrm{hr}$. Species composition of fish creeled was as follows: cutthroat trout - 56 percent, brook trout - 25 percent, rainbow trout - 10 percent, brown trout - 3 percent, dolly varden - 1 percent, and mountain whitefish - 5 percent. Average total length of trout creeled was $20.6 \mathrm{~cm}$ (range, $13.2-33.7 \mathrm{~cm}$ ). Mountain whitefish averaged $36.1 \mathrm{~cm}$ in total length. The average weight of trout creeled was $78 \mathrm{~g}$, compared to $451 \mathrm{~g}$ for the mountain whitefish. Due to the small size of the trout, many were caught and released by the fishermen.

Approximately 64 percent of the fishermen were from out-of-state, with 33 percent coming from the adjacent parts of northern Idaho. Average length 
TABLE 10. ESTIMATED FISHING PRESSURE OBSERVED ON THE ST. REGIS RIVER FOR TWO PERIODS DURING THE SUMMERS OF 1974 AND 1975.

\begin{tabular}{|c|c|c|c|c|c|c|}
\hline \multirow{3}{*}{ Zone } & \multicolumn{3}{|c|}{$\mathrm{hrs} / \mathrm{km}$} & \multicolumn{3}{|c|}{$\mathrm{hrs} / \mathrm{km}$} \\
\hline & Nonstudy & \multirow{2}{*}{\multicolumn{2}{|c|}{$\begin{array}{l}\text { Study Sections } \\
\text { Altered* Unaltered }\end{array}$}} & \multirow{2}{*}{$\begin{array}{r}\text { Nonstudy } \\
\text { Areas }\end{array}$} & \multicolumn{2}{|c|}{ Study Sections } \\
\hline & & & & & Altered* & Unalteredt \\
\hline \multicolumn{7}{|c|}{1974} \\
\hline & \multicolumn{3}{|c|}{ July $1-31$} & \multicolumn{3}{|c|}{ Aug. 1-Sept. 2} \\
\hline I & 26 & 74 & 24 & 14 & 0 & 0 \\
\hline II & 33 & 0 & 23 & 17 & 0 & 30 \\
\hline III & 21 & 31 & 27 & 21 & 0 & 0 \\
\hline IV & 34 & -- & 103 & 36 & -- & 39 \\
\hline V & 66 & -- & 55 & 53 & -- & 16 \\
\hline Ave. & 38 & 36 & 58 & 31 & 0 & 19 \\
\hline
\end{tabular}

July $1-31$

Aug . 1-Sept. 1

$\begin{array}{lrrrrrr}\text { I } & 66 & 32 & 70 & 42 & 66 & 26 \\ \text { II } & 46 & 130 & 178 & 32 & 0 & 0 \\ \text { III } & 39 & 10 & 79 & 21 & 44 & 84 \\ \text { IV } & 47 & -- & 128 & 28 & -- & 130 \\ \text { V } & \frac{38}{46} & \frac{--}{39} & \frac{41}{98} & \frac{45}{34} & \frac{--}{41} & \frac{125}{92} \\ \text { Ave. } & & & & \end{array}$

\footnotetext{
* Both old and newly altered sections.

+ Both unaltered and partially altered.
} 
of each day's fishing was 2.7 hrs. Types of bait used was divided eveniy between flies and live bait ( 46 percent each), with the remainder comprised of lures or a combination of baits. 


\section{SECTION $V$ \\ DISCUSSION}

Physical, chemical and biological factors are all important in the creation and maintenance of good trout habitat. Altering any of the above factors may be detrimental to a given trout population.

The chemical makeup of the water in the St. Regis River is dependent upon the substrate and geological makeup of the drainage. Chemical changes caused by the new channel alterations were not detectable throughout the course of this study. Changes in the water chemistry are probably long-term, gradual changes caused by the accumulation of channel alterations over the yeurs.

The physical changes caused by channelizations and alterations are readily detectable. Differences were shown in sinuousity, pool-riffle periodicity and the variations in depth, width and water velocity between altered and unaltered sections. "Old" channelizations as noted both by Bayless and Smith ${ }^{13}$ and in this study do not readily return to an unaltered meandering condition unassisted. Stabilizing one of the banks with riprap is sufficient to prevent any stream meandering over a long period of time (50 years or more).

Newly altered sections with mitigating structures caused the thalweg to move back and forth across. the channels and created bottom contours which approximated unaltered conditions. In 1974, a year after the mitigating structures in sections 7 and 8 were completely installed, cutthroat trout numbers increased dramatically (Table 11, Appendix). The stepdams placed in section 2 were less successful in restoring trout habitat. The flood in 1974 destroyed most of these dams, turning them into a random rock arrangement. Some of the jetties in section 8 were also lost during this high water, which points to the need for better engineering and placement of such structures.

The loss of vegetative bank cover was complete along most of the newly altered sections. The importance of overhanging bank cover along small streams was 
demonstrated by Hunt ${ }^{6}$ and Boussu ${ }^{14}$. The large amount of riprap used along the newly altered sections of the St. Regis did provide some bank cover for trout.

No single physical parameter measured during this study was well correlated with the trout or whitefish populations. The number of pools per section as measured by pool riffle periodicity provided the best correlation to trout populations $(r=0.49)$. A combination of the many interrelated parameters probably best describes the change in fish populations caused by channelization.

Sections 7 and 8 showed sharp increases in numbers and biomass of trout after mitigating devices had been in effect for one year. In 1974 and 1975, the biomass of trout in section 7 increased by 89 and 207 percent, and in section 8 by 175 and 173 percent, respectively, over 1973 levels. During this same period, trout populations were decreasing or remaining stable in the unaltered, partially altered and "old" altered sections in zones I and II. Increased numbers of age I and II cutthroat trout in sections 7 and 8 (Table 12, Appendix) accounted for the higher biomasses recorded.

Estimates of trout population in the lower two zones were probably low because of harvest by sport fishermen prior to electrofishing operations. Estimates were not made until late August each year after much of the pressure had occurred. This fact must be considered if estimates made after I-90 construction are to be compared to baseline data gathered here. Fishing had little effect on the population comparisons made in the upper zones because most of it occurred after the estimates were made each year. 


\section{SECTION VII}

\section{REFERENCES}

1. Alvord, W., and J.C. Peters. Channel changes in thirteen Montana streams. Montana Fish \& Game Dept. Helena, Montana. 1963. 23 p.

2. Fiser, A.A. Fish populations of a trout stream in relation to major habitat zones and channel alterations. Trans. Amer. Fish. Soc., 97(4): 389-397. 1968 .

3. Irizarry, R.A. The effects of stream alterations in Idaho. Idaho Fish and Game. Boise, Idaho. Job Comp. Rep. Project F 55-R-2. April 1960. 26 p.

4. Congdon, J.C. Fish populations of channelized and unchannelized sections of the Chariton River, Missouri. Dept. of Fish Mgt. Jefferson City, Missouri. $12 \mathrm{p}$.

5. Tarplee, W.H. Jr., D.E. Louder, and A.J. Weber. Evaluation of the effects of channelization of fish populations in North Carolina's coastal plain streams. North Carolina Wildlife Resources Commission. Raleigh, N.C. 1971. 22 p.

6. Hunt, R.L. Responses of a brook trout population to habitat development in Lawrence Creek. Dept. of Nat. Res., Madison, Wisconsin. Tech. Bul1. No. 48. 1971. 35 p.

7. Shetter, D.S., O.H. Clark, and A.S. Hazzard. The effects of deflectors in a section of a Michigan trout stream. Trans. Amer. Fish. Soc., 76: 248-278. 1946.

8. Latta, W.C. The effects of stream improvement upon the anglers' catch and standing crop of trout in the Pigeon River, Otsego County, Michigan. Michigan Dept. of Nat. Res. Research and Development Report No. 265. May 1972. 57 p.

9. Barton, J.R., D.A. White, P.V. Winger, and E.J. Peters. The effects of highway construction on fish habitat in the Weber River, near Henefer, Utah. Bur. Reclam. Rep. REC-FRC-72-17. June 1972. p. $17-28$.

10. Ricker, W.E. Handbook of computations for biological statistics of fish populations. Fish. Res. Bd. Can. Bull., 119: 1-300. 1958.

11. Snedecor, G.W., and W.G. Cochran. Statistical methods, sixth ed. Ames, The Iowa State Univ. Press. 1967. p. 62.

3.2. Leopold, L.B., M.G. Wolman, and J.P. Miller. Fluvial processes in geomorphology. San Francisco and London, Freeman and Co. 1964. $522 \mathrm{p}$. 
13. Bayless, J., and W.B. Smith. The effects of channelization on the fish populations of lotic waters in eastern North Carolina. North Carolina Wild1. Resource Comm. Raleigh, N.C. 1964. 15 p.

14. Boussu, M.F. Relationship between trout populations and cover on a small stream. Jour. Wid1. Mgt., 18(2): 229-239. April 1954. 
SECTION VIII

APPENDIX

$-41-$ 


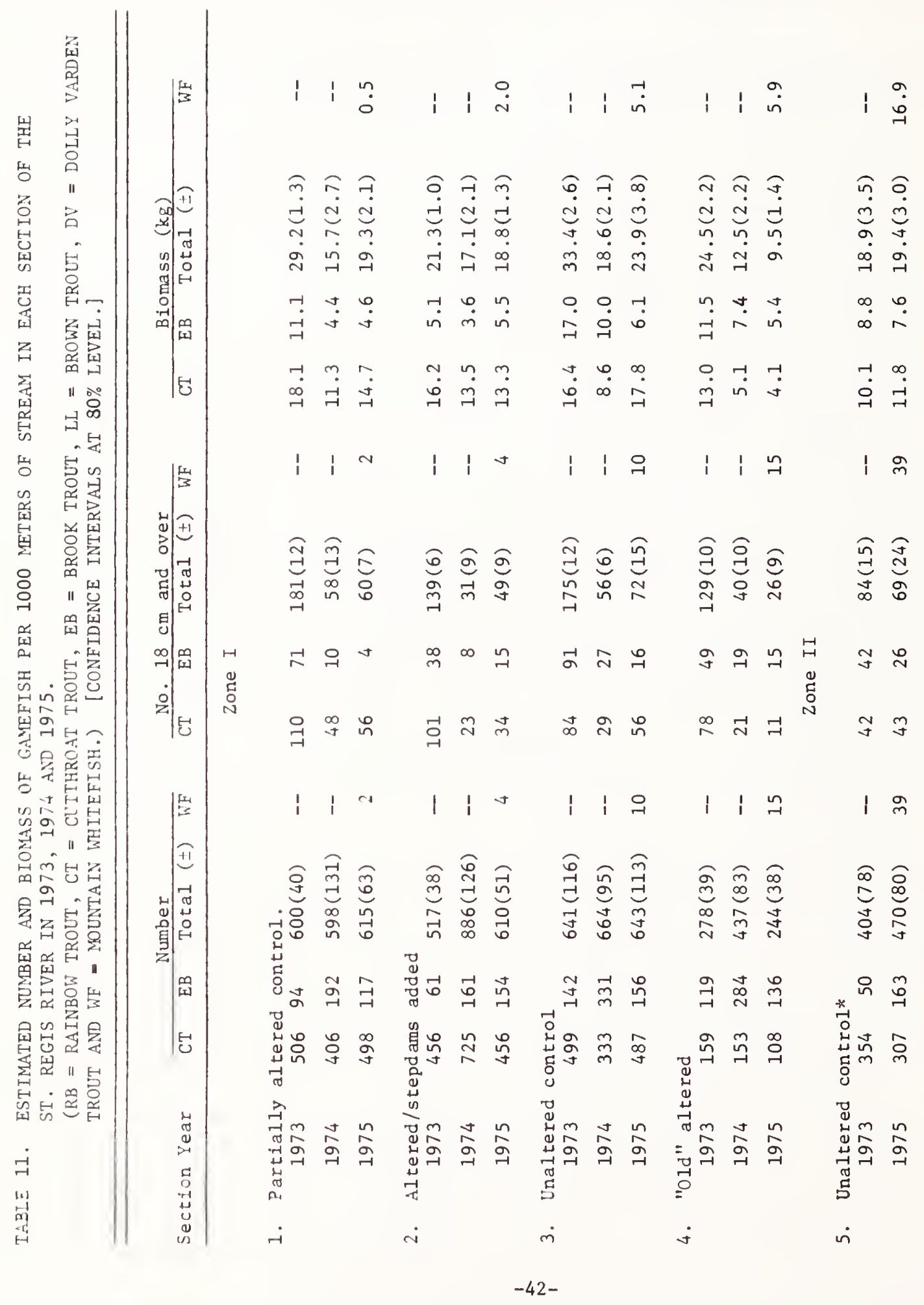




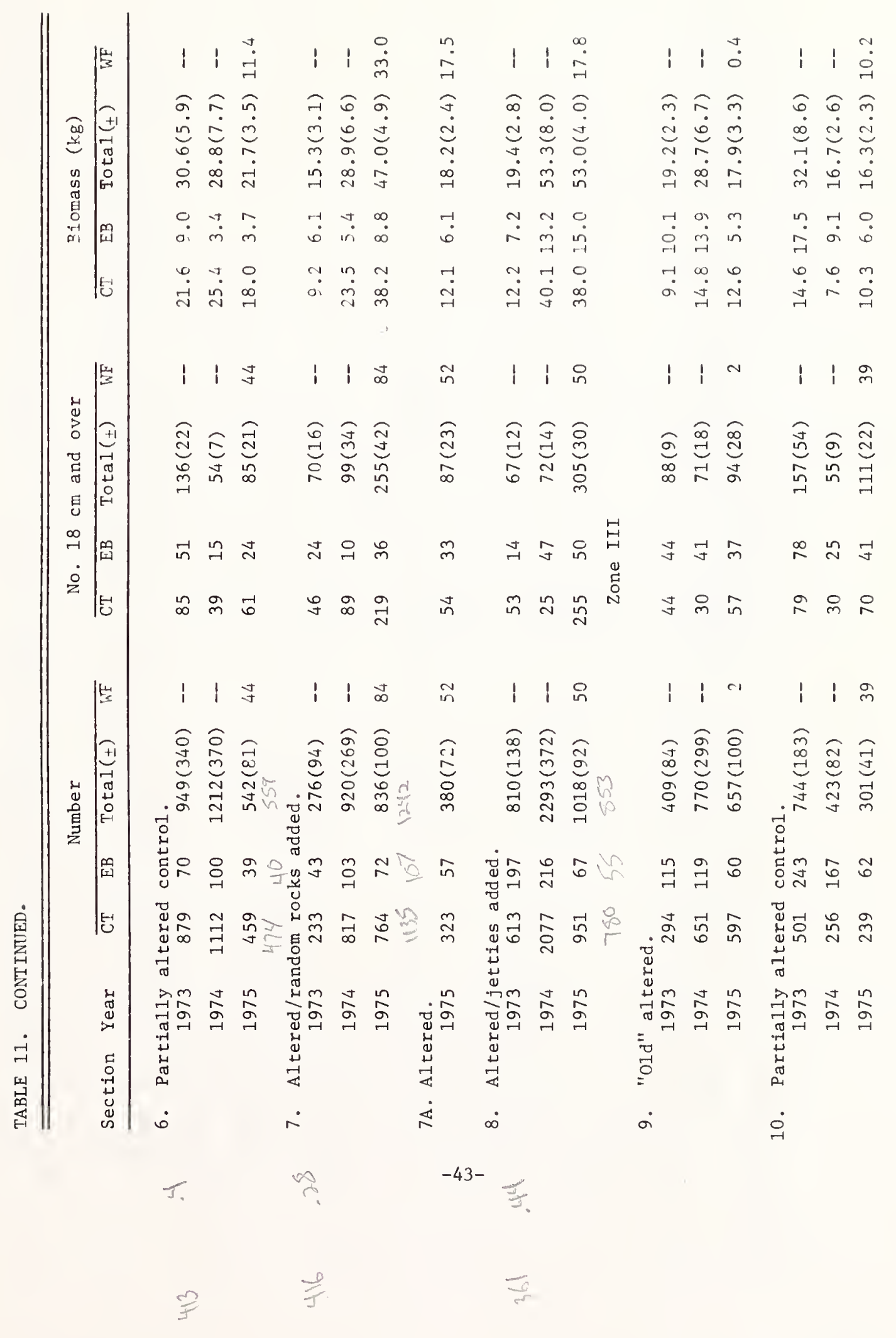




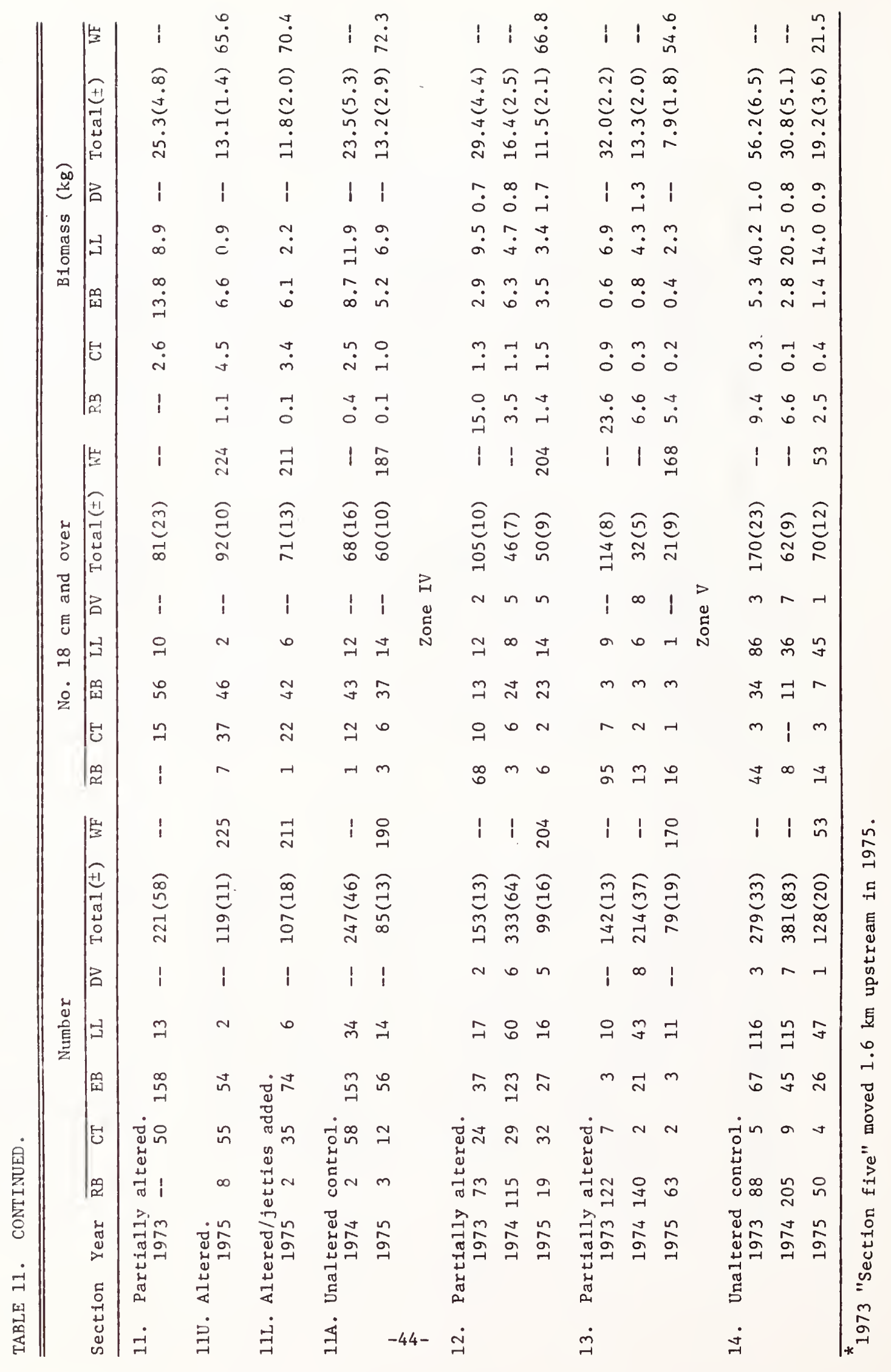




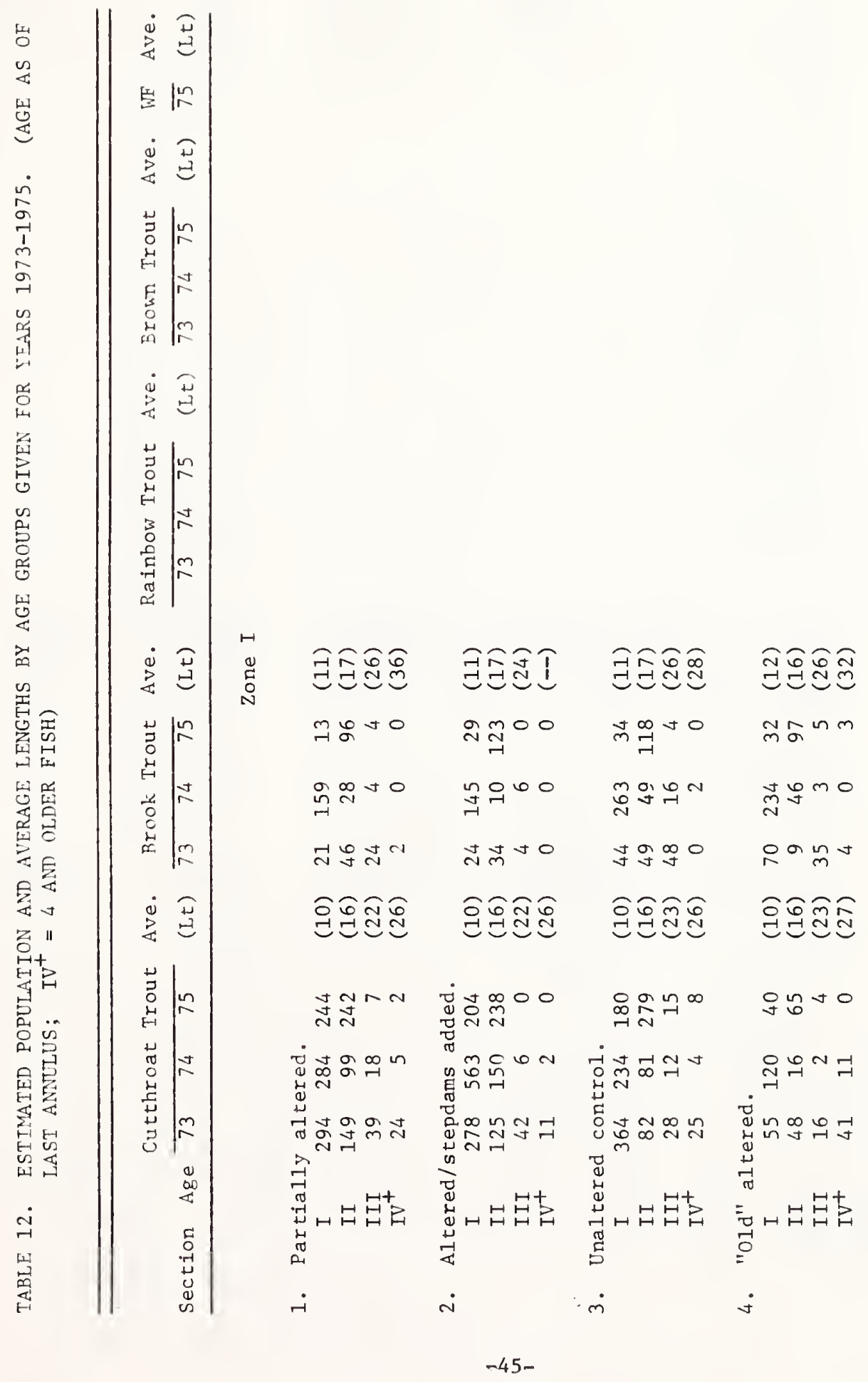




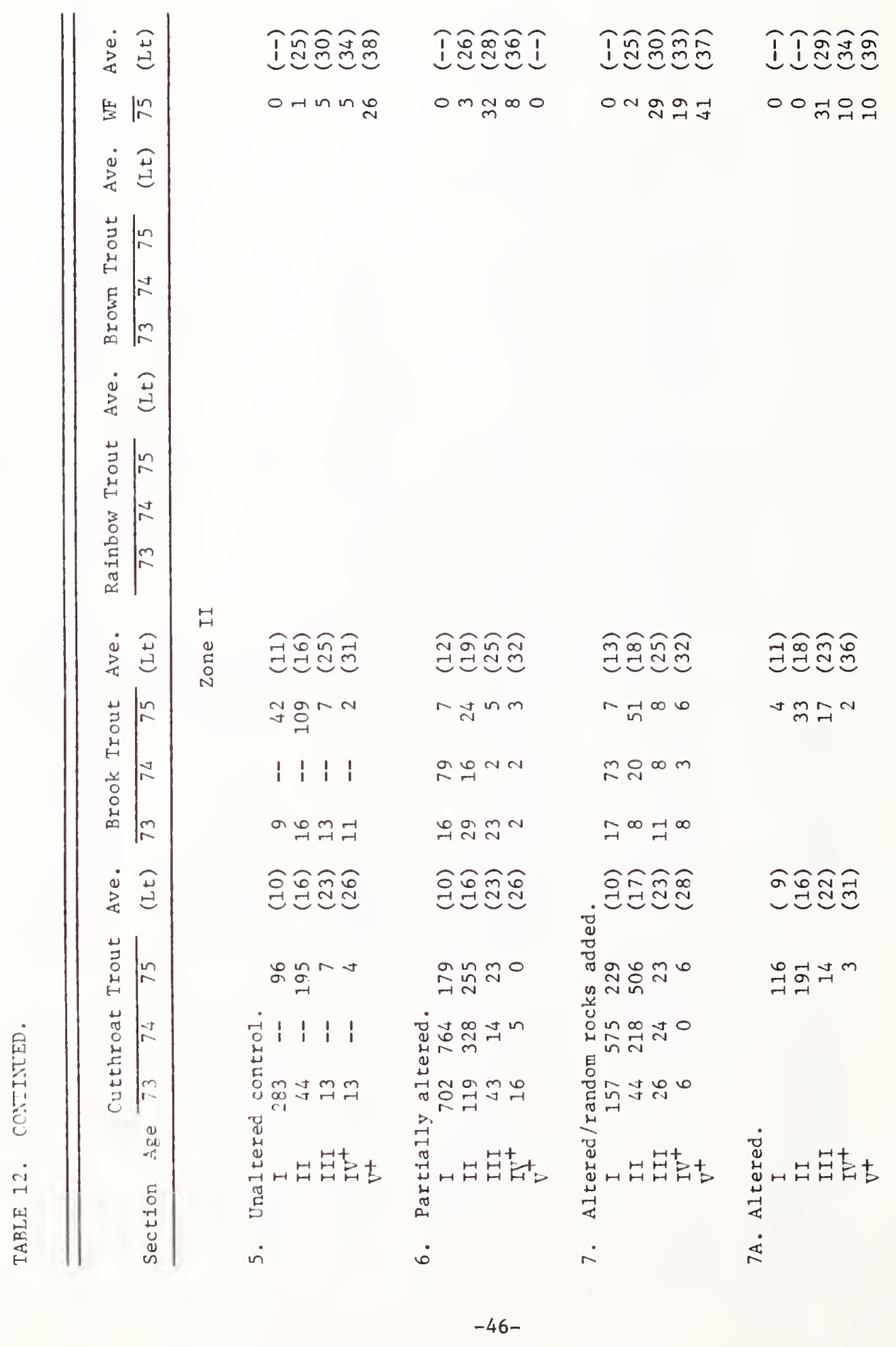




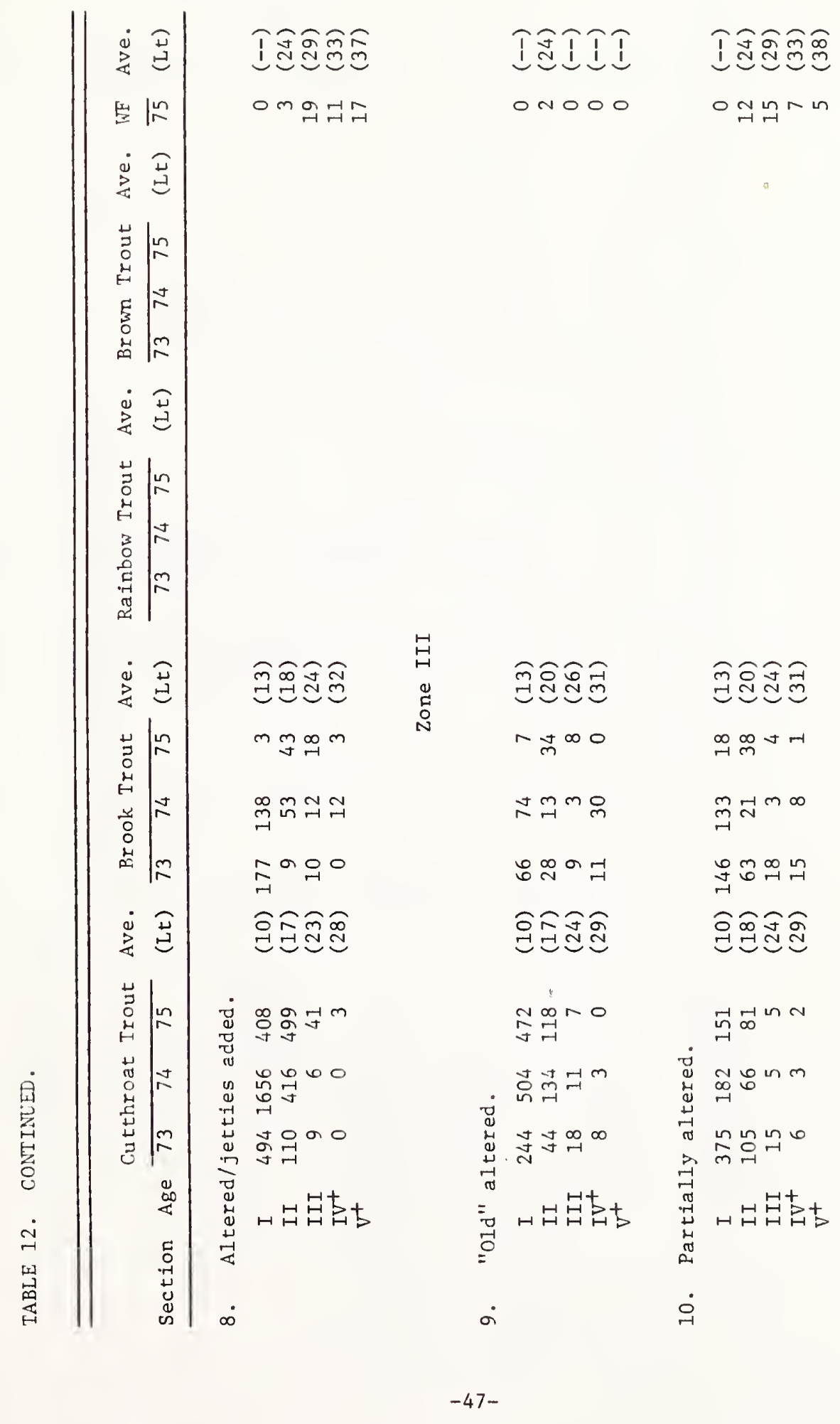




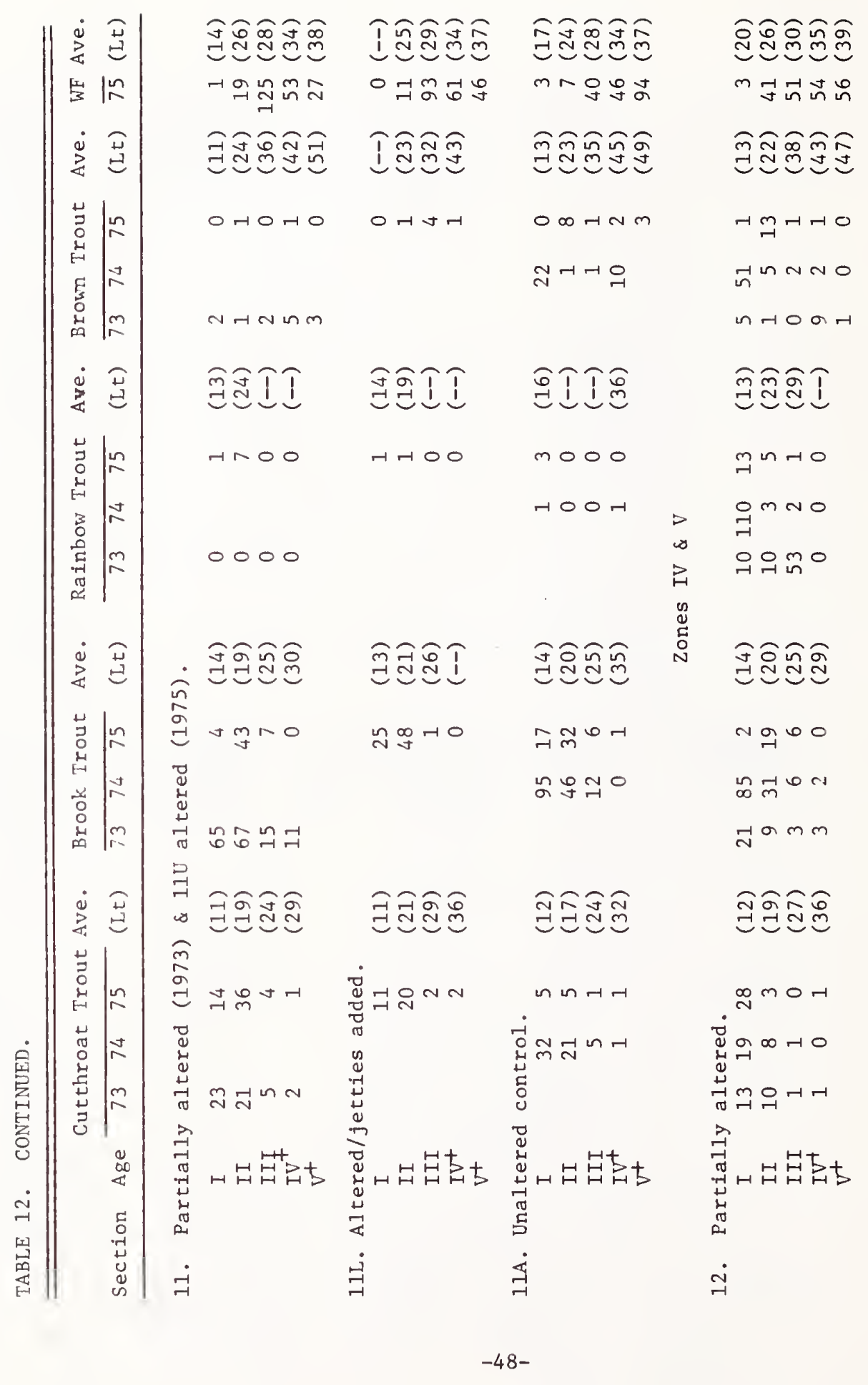







